\title{
Metallothionein $2 A$ gene polymorphisms in relation to diseases and trace element levels in humans
}

\author{
Ankica Sekovanić, Jasna Jurasović, and Martina Piasek \\ Analytical Toxicology and Mineral Metabolism Unit, Institute for Medical Research and Occupational Health, Zagreb, \\ Croatia
}

[Received in October 2019; Similarity Check in October 2019; Accepted in March 2020]

\begin{abstract}
Human metallothioneins are a superfamily of low molecular weight intracellular proteins, whose synthesis can be induced by essential elements (primarily $\mathrm{Zn}$ and $\mathrm{Cu}$ ), toxic elements and chemical agents, and stress-producing conditions. Of the four known isoforms in the human body MT2 is the most common. The expression of metallothioneins is encoded by a multigene family of linked genes and can be influenced by single nucleotide polymorphisms (SNPs) in these genes. To date, 24 SNPs in the MT2A gene have been identified with the incidence of about $1 \%$ in various population groups, and three of them were shown to affect physiological and pathophysiological processes. This review summarises current knowledge about these three SNPs in the MT2A gene and their associations with element concentrations in the body of healthy and diseased persons. The most investigated SNP is rs28366003 (MT2A-5 A/G). Reports associate it with longevity, cancer (breast, prostate, laryngeal, and in paranasal sinuses), and chronic renal disease. The second most investigated SNP, rs10636 (MT2A+838G/C), is associated with breast cancer, cardiovascular disease, and type 2 diabetes. Both are also associated with several metal/metalloid concentrations in the organism. The third SNP, rs1610216 (MT2A $-209 \mathrm{~A} / \mathrm{G}$ ), has been studied for association with type 2 diabetes, cardiomyopathy, hyperglycaemia, and $\mathrm{Zn}$ concentrations. Metallothionein concentrations and $M T 2 A$ polymorphisms have a potential to be used as biomarkers of metal exposure and clinical markers of a number of chronic diseases. This potential needs to be studied and verified in a large number of well-defined groups of participants (several hundreds and thousands) with a focus on particular physiological or pathological condition and taking into consideration other contributing factors, such as environmental exposure and individual genetic and epigenetic makeup.
\end{abstract}

KEY WORDS: metals and metalloids; rs28366003; rs10636; rs1610216; single nucleotide polymorphism

Pollution has been recognised as a major global health threat. Although exposure to various pollutants, including toxic metals or mixtures of environmental stressors is widespread, the development of diseases caused by direct environmental exposure is, luckily, limited. Whether the disease develops will depend on the causative agent, exposure levels and duration, the period of life when exposure occurs, age, and sex. Other factors that may contribute to the development and progression of a disease include other condition or disease, dietary habits, physical activity, medications taken, and variation in genetic susceptibility (1-3).

In the course of our continuing study of the exposure, health risks, and effects of the main toxic and essential elements lead $(\mathrm{Pb})$, cadmium $(\mathrm{Cd})$, mercury $(\mathrm{Hg})$, arsenic (As), zinc $(\mathrm{Zn})$, copper $(\mathrm{Cu})$, iron $(\mathrm{Fe})$, and selenium $(\mathrm{Se})$, we recently came across increasing evidence of a link between the levels of these elements in the body of healthy and diseased persons and specific gene polymorphisms of metallothioneins (MTs). This motivated us to prepare an overview of the relationships between element levels and three most studied single nucleotide polymorphisms (SNPs)

Corresponding author: Ankica Sekovanić, Institute for Medical Research and Occupational Health, Ksaverska cesta 2, HR-10000 Zagreb, Croatia, E-mail: asekovanic@imi.hr of the MT2A gene, namely rs28366003, rs1610216, and rs10636. For the purpose of this review, we searched PubMed database for articles indexed until the end of 2019 using this keyword combination: metallothionein AND polymorphism AND human. The query yielded 113 matches, and the first article on specific $M T 2 A$ polymorphism was from 2005 . We excluded 13 review articles, two letters to the editor, and 62 articles dealing with SNPs other than $M T 2 A$. This review has no intention whatsoever to present these gene polymorphisms as either the main or only contributing factors to element levels in the human body or to the development of chronic diseases, including malignancies, nor does it go into detail of the reported studies. Instead we compare their findings in a series of tables and comment on the relationships between rs28366003 and toxic metal levels in the human body only where we compare them with our own findings (4).

\section{BIOLOGICAL SIGNIFICANCE OF METALLOTHIONEINS}

Metallothioneins are a superfamily of cysteine-rich, intracellular, metal-binding proteins present in plants, vertebrates, invertebrates, eukaryotes, and prokaryotes. 
Historically, the discovery of MTs has closely been related to the study of $\mathrm{Cd}$. The earliest work in this area was reported in 1941 by Maliuga, whereas the data on Cdbinding protein isolated from equine renal cortex, later named metallothionein, were first reported by Margoshes and Vallee in 1957 (reviewed in 5-9). Since then, MT has been of great interest in many scientific disciplines, including toxicology, biological and physical chemistry, molecular biology, and various clinical and cancer studies with about 10,000 published papers (7-9). The characteristics of MTs are low molecular mass of 6-7 kDa, high cysteine content (about $30 \%$ ), no aromatic amino acid, and high binding affinity for metals, particularly for $\mathrm{Zn}, \mathrm{Cu}$, and $\mathrm{Cd}$. The amounts and ratios of metals bound by the thiol $(-\mathrm{SH}$, mercaptide) group will depend on the tissue; human liver MTs mostly contain $\mathrm{Zn}$ and small amounts of $\mathrm{Cu}$, while renal cortex MTs mostly contain $\mathrm{Cd}$, then $\mathrm{Zn}$, and then $\mathrm{Cu}$ (reviewed in 5, 8-12).

In mammals, including humans, there are four main groups of MTs with different sequences, expression, and characteristics: MT1, MT2, MT3, and MT4. Isoforms MT1 and MT2 are expressed in almost all tissues. MT3 is expressed mainly in the brain, and to a lesser extent in the heart, kidneys, and reproductive organs (reviewed in 8-10, 13-15). MT4 is expressed in the epithelial cells of the skin and mucosa (16). MT molecules are single-chain polypeptides, which contain 61 to 68 amino acids, and 20 of them are cysteine, ordered in the sequences Cys-Cys, Cys- $\mathrm{x}-\mathrm{Cys}$, and Cys- $\mathrm{x}-\mathrm{y}-\mathrm{Cys}$ ( $\mathrm{x}$ and $\mathrm{y}$ are amino acid which are not cysteine) $(8-10,17)$. Cysteine sulphur atoms are responsible for binding divalent metals in two clusters of MTs, connected with a sequence which does not contain cysteine. Amino acids 1 to 30 form a stable $\alpha$-cluster (C-terminal) with four metal binding sites, whereas amino acids 31 to 68 form a reactive $\beta$-cluster (N-terminal) with three binding sites for divalent metals ions. Therefore, each MT molecule can bind up to seven divalent ions of $\mathrm{Zn}, \mathrm{Cd}$, $\mathrm{Hg}$, and $\mathrm{Pb}, 12$ of $\mathrm{Cu}$, and 18 of $\mathrm{Ag}$. Four metal ions first fill the $\alpha$-cluster, and remaining three ions enter the $\beta$-cluster. Metals bound to the $\beta$-cluster are released more easily than metals bound to the $\alpha$-cluster $(8,10,13,15,18)$. The order of metal-binding affinities was tested by in vitro studies on rat liver in the 1980s and the reports are not uniform: $\mathrm{Cd}>\mathrm{P} \mathrm{b}>\mathrm{Cu}>\mathrm{Hg}>\mathrm{Zn}>\mathrm{A} \mathrm{g}>\mathrm{Ni}=\mathrm{Co}$ ( 19 ), $\mathrm{Hg}>\mathrm{Cu}>\mathrm{Cd}>\mathrm{Zn}>\mathrm{Ni}=\mathrm{Co}(20)$, and $\mathrm{Hg}>\mathrm{Ag}>>\mathrm{Cu}>\mathrm{Cd}>\mathrm{Zn}$ (21). Many metals have the affinity for MT but only $\mathrm{Cu}^{+}$, $\mathrm{Cd}^{2+}, \mathrm{Pb}^{2+}, \mathrm{Ag}^{+}, \mathrm{Hg}^{2+}$, and $\mathrm{Bi}^{2+}$ can displace $\mathrm{Zn}^{2+}$ in $\mathrm{MT}$, which was confirmed in the horse kidney in vitro (22) and in the rat liver in vivo studies (23). Exchanges between $\mathrm{Zn}$ and $\mathrm{Cd}$ happen rapidly in the $\beta$-cluster, contrary to their slow exchange in the $\alpha$-cluster. Zinc readily dissociates from MT to make itself available for different biological functions and to stimulate further MT synthesis. Metallothioneins serve as metal ion donors to other ligands or proteins (reviewed in 13, 24, 25). Their degradation depends on metals bound, their distribution in MT molecules, and the medium. Acidic media are known to speed up metal dissociation from MTs. MTs completely saturated with metals are more resistant to degradation by lysosomal proteases than unsaturated MTs or apothioneins (apo-MTs, that is MTs free of metals). In neutral media, MTs saturated with metals are less resistant to degradation than apo-MTs (25-28).

The synthesis of MTs is induced by numerous factors such as metals and metalloids, various chemical agents, including acetaminophen (paracetamol), cytokines, and many other stress-producing conditions, including oxidative stress, infection and inflammation. The peculiar chemical structure of MTs gives them their molecular stability and specificity and defines their role in various physiological and pathological conditions $(8-11,29-33)$. Their main biological function is to maintain the homeostasis of essential metals $\mathrm{Zn}$ and $\mathrm{Cu}$ (reviewed in 12). Studies conducted in vitro showed reactivation of apo-enzymes in which $\mathrm{Zn}$ or $\mathrm{Cu}$ were cofactors (alkaline phosphatase, superoxide dismutase and others) after incubation with $\mathrm{Zn}-\mathrm{MT}$ or Cu-MT. The mechanism of $\mathrm{Zn}$ donation from MT to apo-enzyme is still unknown, but it is assumed that MT binds to an MT-releasing factor, which displaces Zn and makes it available to enzymes $(8,14)$. It has been shown that MTs participate in Zn regulation by intestinal absorption and excretion. When $\mathrm{Zn}$ intake is high, MTs may have a crucial role in restricting its absorption by storing it in the enterocytes and enabling its transfer back to the gut lumen, as confirmed by studies on knockout and transgenic mice (34-39). The induction of intestinal MT by $\mathrm{Zn}$ and its interaction with $\mathrm{Cu}$ is used in the therapy of patients with Wilson's disease with Zn acetate, a US Food and Drug Administration-approved drug. Wilson's disease is a rare autosomal recessive inherited disorder of $\mathrm{Cu}$ metabolism characterised by the accumulation of excessive amounts of $\mathrm{Cu}$ in the liver, brain, and eyes. The mechanism of $\mathrm{Zn}$ action as an anti-copper agent involves inhibition of both $\mathrm{Cu}$ absorption from the gastrointestinal tract and its transfer into the circulation by capturing the $\mathrm{Cu}-\mathrm{MT}$ complex in the mucosal cell and its ultimate faecal excretion $(40,41)$.

Metallothioneins have multiple roles. Besides its main function to keep essential elements in balance, they protect the body against free radicals and toxic effects of metal ions (reviewed in 8-10, 13, 24, 42-46). High levels of MTs can be found in foetal and neonatal liver, but these drop to the levels found in adults during the postnatal period. Increased liver MT levels during prenatal period in all mammalian species are believed to protect against potentially toxic $\mathrm{Zn}$ and $\mathrm{Cu}$ ions before the intestinal control mechanisms develop (46-49). Another important role of MTs is to protect against oxidative stress caused by various environmental stressors, including toxic metals. Experimental studies showed lower acute hepatotoxicity of $\mathrm{Cd}$ due to induced MT synthesis and high Cd binding to cytosolic MT, which reduces exposure of target organelles to $\mathrm{Cd}$ (reviewed in 32). Studies conducted on knock out 
mice showed that those without MT expression were more sensitive to $\mathrm{Cd}$ toxicity than control mice. The protective effects of MTs are generally clear against acute metal toxicity and carcinogenicity but not as much against chronic metal toxicity, to be addressed later in the text $(8,50-52)$. In general, large amounts of -SH groups in MT molecule enable reaction with numerous electrophilic chemicals, as they catch free radicals such as hydroxyl, superoxide or nitric oxide radicals produced during metabolism of xenobiotics $(33,53,54-57)$.

Other important roles of MTs involve cell survival, inhibition of apoptosis, angiogenesis and vascular remodelling, and immunomodulation. Studies on human umbilical vascular endothelial cells (HUVECs) have shown that a homedomain protein HMBOX1, which acts as a transcription factor and is abundantly expressed in the cytoplasm of the endothelial cells, maintains cell survival by promoting autophagy and inhibiting apoptosis by interaction with MT2, which increases intracellular free Zn (58). This role of MTs in vascular remodelling is important in the development of atherosclerosis and malignant tumours. Furthermore, MTs seem to inhibit pro-inflammatory cytokines, such as interleukins IL-6 and IL-12 and tumour necrosis factor TNF- $\alpha$, and can therefore supress inflammation (59). Investigations on MT-null mice showed higher susceptibility to the hepatotoxic effects of the antiinflammatory drug paracetamol (acetaminophen), which points to the protective role of MTs against chemically induced hepatotoxicity $(60,61)$. The protective antioxidant role of MTs against radiation-mediated immunosuppression and cell damage was confirmed in experiments on MT-null mice $(62,63)$.

\section{REGULATION OF METALLOTHIONEIN SYNTHESIS AND MT2A POLYMORPHISMS}

Synthesis of MTs in humans is encoded by a cluster of genes located in the q13 locus of chromosome 16 (16q13). Until now, 17 genes have been identified in this cluster, and at least 11 of them are functional; eight among MT1 isoforms (MT1A, MT1B, MT1E, MT1F, MT1G, MT1H, $M T 1 M / M T 1 K$, and $M T 1 X)$, and the other three have only one functional gene (MT2A, MT3, and MT4) (reviewed in $8-12,15,45,64-67)$. The genes consist of two to three exons and one to two introns. Elements that control MT transcription can be divided in basal and inducible. The basal elements of gene sequence are the TATA-box, GCbox, and at least two basal level enhancer (BLE) sequences. The promoter region of the MT1 and MT2 genes involve inducible elements that consist of different types of responsive elements: metal response elements (MREs), glucocorticoid response elements (GREs), and antioxidant response elements (AREs). The most investigated mechanism of MT gene transcription by metal ions is via several MREs located in 5' untranslated region (UTR) of the gene (67-69). Early studies showed that metal transcription factor 1 (MTF-1) binds to MREs in the promoter regions of MT genes via $\mathrm{Zn}$ finger transcription (Cys2-His2) factor controlling the expression of the MT1 and MT2 genes. Besides Zn, MTF-1 can be activated by reactive oxygen species, tyrosine-specific protein kinase, protein kinase C, and c-Jun N-terminal kinase (68-72).

Metal ions other than Zn can induce MT synthesis by mechanisms different than the one described above. Toxic metals cannot activate MTF-1 and, due to high binding affinity for MT, they replace Zn ions in MT molecules and thus increase intracellular $\mathrm{Zn}$ levels (reviewed in 13-15, 24). Free $\mathrm{Zn}$ then stimulates further synthesis of MT by binding to MTF-1, which then binds to MRE and ultimately has impact on metal toxicity. In other words, under conditions of acute exposure to high doses of toxic metals such as $\mathrm{Cd}$ or $\mathrm{Hg}$, higher MT expression may reduce their toxicity. However, in chronic exposure to either of the toxic metals ( $\mathrm{Cd}$ or $\mathrm{Hg}$ ), increased MT synthesis leads to prolonged retention of that metal in the body, which increases the risk of toxic effects. In addition, increased MT may capture essential elements in internal organs, primarily $\mathrm{Zn}$ in the liver, making them less available for their physiological roles such as transfer to the developing foetus through placenta during pregnancy (reviewed in 8,73).

Metallothionein expression can be induced by oxidative stress when generated hydrogen peroxide $\left(\mathrm{H}_{2} \mathrm{O}_{2}\right)$ radicals oxidise MT, and $\mathrm{Zn}$ is released, which then activates MTF1 (64). Glucocorticoids also regulate MT transcription by binding to their response elements (GREs) in the promoter region of the MT genes (74). MT expression can be also induced also by tissue hypoxia (75), catecholamines (76), or hypothermia (77).

Single nucleotide polymorphisms (SNPs) are genetic variations characterised by the replacement of one nucleotide with another in a certain stretch of DNA, which occurs in at least $1 \%$ of the population and differs between population groups. Given their location, SNPs can either be in the coding or non-coding gene region. Those in the coding region may affect amino acid arrangement or influence protein kinetics, mRNA structure, and stability, while SNPs in the promoter region or other regulatory gene regions affect protein production (reviewed in 67, 78). According to the National Center for Biotechnology Information (NCBI) database on polymorphism, dbSNP (79), 24 polymorphisms in the MT2A gene have been identified in humans, three of which may affect physiological and pathophysiological processes. The most studied SNP in $M T 2 A$ was rs28366003 $(-5 \mathrm{~A} / \mathrm{G})$, followed by rs 10636 $(+838 \mathrm{G} / \mathrm{C})$, whereas $\mathrm{rs} 1610216(-209 \mathrm{~A} / \mathrm{G})$ has been the least investigated. Only Starska et al. $(80,81)$ and Krześlak et al. (82) studied all three MT2A SNPs and their associations with several malignant tumours in a Polish population.

Below we describe these and other information about $M T 2 A$ polymorphisms with the focus on reported relationships with trace elements. We set up three sets of 
interrelated tables, in which we present the following groups of data for each SNP: 1) literature data on the related genotype frequencies; 2) reported associations with human diseases; and 3) reported associations with element concentrations in humans. Of the 36 selected references, 21 deal with relationships with elements (in healthy and/ diseased persons), 13 with diseases only, and two with genotype frequencies only.

\section{MT2A polymorphism rs28366003}

The rs28366003 $(M T 2 A-5 \mathrm{~A} / \mathrm{G}) \mathrm{SNP}$ is an $\mathrm{A} / \mathrm{G}$ substitution that occurs in the core promoter region of the $M T 2 A$ gene between the TATA box and the site where the transcription begins. As it occurs near 5'UTR, it can affect MT transcription through reduced MTF-1 binding on MRE (reviewed in 11, 67). A study on human embryonic kidney cells 293 (HEK 293) showed that substitution of the A allele with the $\mathrm{G}$ allele near 5'UTR reduced $\mathrm{Cd}$-induced transcription. Reduced MT transcription can therefore affect element concentrations in the body and adversely affect health $(46,83)$.

Studies of the rs28366003 SNP were mostly conducted in Turkish and Polish populations, but several were also done in Japan and the United States, China, Thailand, Spain, and Croatia. Table 1 shows the frequencies of AA, AG, and GG genotypes reported in these studies. According to the literature data, the frequency of the AA genotype ranges from $84.0 \%$ to $95.5 \%$ in healthy Polish (80-82, 84-88), $86.0 \%$ to $90.4 \%$ in Turkish (89-94), and about $82 \%$ in Japanese population $(95,96)$. The highest frequencies were found in a healthy Spanish population (97.9 \%) (97), US black women (97.9\%) (98), Croatian women (93-94.0\%) $(4,99)$, and a healthy Chinese population (92.5\%) (100). The lowest frequency of $57.8 \%$ and $53.4 \%$ was found in healthy Iranian and Columbian populations, respectively $(101,102)$. The frequency of the AG ranged from $2.1 \%$ in healthy Spanish population (97) and black US women (98) to $37.8 \%$ and $43.6 \%$ in Iranian and Columbian population, respectively $(101,102)$. We conducted the first study of that kind in Croatia and found that nearly $6 \%$ of the healthy postpartum women were G allele carriers (4). Several authors reported higher percentages of $\mathrm{G}$ allele carriers in case study groups than controls $(80,84,97,100)$, and others reported no differences $(88,96)$. Higher frequency of $A G$ genotype was reported among white $(12.8 \%)$ than black $(2.1 \%)$ women in the USA (98).

Table 2 summarises associations between the rs28366003 SNP and various clinical entities reported in literature. The associations were found for different types of cancers in the breast, prostate, paranasal sinus, larynx and stomach $(31,80-82,84-87,100,101)$ and chronic diseases, such as type 2 diabetes mellitus, chronic kidney disease (95), and neovascular and dry forms of age-related macular degeneration (97). Several studies reported no association between rs28366003 SNP and prostate cancer
(88), type 2 diabetes mellitus (103), or sporadic amyotrophic lateral sclerosis (96).

Table 3 summarises association between rs28366003 SNP and element levels in various healthy population groups or subjects with defined disease. These findings are controversial, as a number of studies found correlations with element concentrations in the human organism (84-86, 89-91, 104) and others did not $(95,99,102,105,106)$.

In our recent study in healthy Croatian postpartum women (4) we found no significant association between rs28366003 and either $\mathrm{Cd}$ or $\mathrm{Pb}$ concentrations in the placenta and maternal and cord blood, although stepwise multiple regression analysis showed marginal contribution of this SNP to higher placental $\mathrm{Cd}$ and $\mathrm{Pb}$, maternal $\mathrm{Pb}$, and cord blood Cd concentrations. We did find lower placental Fe in non-smoking $\mathrm{G}$ allele carriers (persons with $\mathrm{AG}$ and GG genotype) than non-smoking persons with the wild AA genotype, which surprised us at first, as Fe-MT binding has mostly been underestimated in literature (reviewed in 107). This result can be at least partly explained by the links between MT and Fe. Conditions of an acidic lysosomal-like environment created in vitro can stimulate MT release of $\mathrm{Zn}$ or $\mathrm{Cu}$, which increases MT expression and facilitates Fe-MT binding (108). Through this mechanism, MT may protect from lysosomal destabilisation due to Fe overloadinduced oxidative stress (reviewed in 109). In contrast to our study in Croatian population $(n=268)$, studies in Turkish population $(89,90)$ reported higher $\mathrm{Cd}(\mathrm{n}=95)$ and $\mathrm{Pb}$ $(n=91)$ concentrations in maternal blood, higher Fe in the umbilical cord blood, lower $\mathrm{Cd}$ in the placenta, and no difference in placental Fe concentrations in non-smoking $\mathrm{G}$ allele carriers vs. persons with the wild AA genotype. However, those studies report an odd discrepancy between high blood and low placental Cd levels. Blood Cd was much higher than reported earlier in non-smoking Turkish population (110) and placental Cd was at the lower end of the scale of the overall placental $\mathrm{Cd}$ levels ever measured and reported in literature between 1976 and 2011 (111). These findings point to an unidentified source of $\mathrm{Cd}$ and/ or analytical error, which may have blurred the association between rs28366003 and metal concentrations. Since studies on the association between this SNP and toxic and essential elements in mother-newborn pairs are inconsistent, further research is needed with a large number of subjects (after either spontaneous delivery or Caesarean section) with defined sources of exposure to toxic metals, including cigarette smoking and dietary habits, as they all may overcome the influence on element levels of this or the other two discussed MT2A SNPs, which, as a rule, have low genotype frequency at the population level. Table 3 shows that population studies of the association between rs28366003 and element levels to date have included between 100 and 700 participants. The only exception is the Japanese study (95), which included $>2700$ participants. More such studies with large population samples are needed. 
Table 1 Genotype frequencies of the rs28366003 (MT2A-5A/G) single nucleotide polymorphism in humans

\begin{tabular}{|c|c|c|c|c|c|c|}
\hline \multirow{2}{*}{$\begin{array}{l}\text { Authors and year of } \\
\text { publication } \\
\text { (reference No.) }\end{array}$} & \multirow{2}{*}{ Ethnicity } & \multirow{2}{*}{$\mathbf{n}$} & \multirow{2}{*}{ Study participants } & \multicolumn{3}{|c|}{ Genotype frequencies (\%) } \\
\hline & & & & AA & AG & GG \\
\hline \multirow{2}{*}{$\begin{array}{l}\text { Stajnko et al., } 2019 \\
\text { (99) }\end{array}$} & Croatian & 136 & Pregnant women & $93.0^{\#}$ & \multicolumn{2}{|c|}{$7.0^{s}$} \\
\hline & Slovenian & 176 & Non-pregnant women & $95.0^{\#}$ & \multicolumn{2}{|c|}{$5.0^{\mathrm{s}}$} \\
\hline \multirow{2}{*}{$\begin{array}{l}\text { Shokrzadeh et al., } 2019 \\
(101)\end{array}$} & \multirow{2}{*}{ Iranian } & 95 & Men and women with gastric cancer & 46.4 & 41.0 & 12.6 \\
\hline & & 90 & Control healthy men and women & 57.8 & 37.8 & 4.4 \\
\hline Sekovanić et al., 2018 (4) & Croatian & 268 & Mother-newborn pairs & 94.0 & \multicolumn{2}{|c|}{$6.0^{\S}$} \\
\hline $\begin{array}{l}\text { González-Martínez et } \\
\text { al., } 2018(102)\end{array}$ & Colombian & 101 & Men and women & 53.4 & 43.6 & 3.0 \\
\hline \multirow{2}{*}{$\begin{array}{l}\text { Białkowska et al., } 2018 \\
(88)\end{array}$} & \multirow{2}{*}{ Polish } & 197 & Men with prostate cancer & 90.9 & \multicolumn{2}{|c|}{$9.1^{\S}$} \\
\hline & & 197 & Control men without prostate cancer & 89.3 & \multicolumn{2}{|c|}{$10.7^{\S}$} \\
\hline Yang et al., 2017 (105) & Thai & 677 & Men and women & 79.5 & 20.5 & 0.0 \\
\hline \multirow{2}{*}{ Liu et al., 2017 (100) } & \multirow{2}{*}{ Chinese } & 459 & Women with breast cancer (various types) & 82.3 & 15.3 & 2.4 \\
\hline & & 549 & Control healthy women & 92.5 & 7.5 & 0.0 \\
\hline \multirow{2}{*}{ García et al., 2017 (97) } & \multirow{2}{*}{ Spanish } & 130 & Men and women with AMD & 88.5 & 11.5 & 0.0 \\
\hline & & 96 & Control healthy men and women & 97.9 & 2.1 & 0.0 \\
\hline \multirow{2}{*}{$\begin{array}{l}\text { Raudenska et al., } 2017 \\
(103)\end{array}$} & \multirow{2}{*}{ Czech } & 70 & Men and women with type 2 diabetes mellitus & 88.6 & 8.6 & 0.0 \\
\hline & & 80 & Control healthy men and women & 86.3 & 13.7 & 0.0 \\
\hline Hattori et al., 2016 (95) & Japanese & 2774 & Men and women & 81.8 & 17.4 & 0.8 \\
\hline \multirow{2}{*}{$\begin{array}{l}\text { Adams et al., } 2015 \\
(104)\end{array}$} & \multirow{2}{*}{ US } & 170 & Premenopausal women & 88.0 & 12.0 & 0.0 \\
\hline & & 151 & Men and women & 84.0 & 15.0 & 1.0 \\
\hline & & 130 & Men and women with SIP & 75.4 & 23.8 & 0.8 \\
\hline Starska et al., 2015 (80) & Polish & 418 & $\begin{array}{l}\text { Control men and women without head or } \\
\text { neck tumour }\end{array}$ & 95.5 & 4.1 & 0.0 \\
\hline & & 117 & Men and women with SIP & 76.1 & 23.1 & 0.8 \\
\hline Starska et al., 2015 (84) & Polish & 132 & $\begin{array}{l}\text { Control men and women with normal } \\
\text { sinonasal mucosa }\end{array}$ & 87.9 & 12.1 & 0.0 \\
\hline & & 323 & Men and women with SCC & 89.2 & 9.9 & 0.9 \\
\hline Starska et al., 2014 (85) & Polish & 116 & $\begin{array}{l}\text { Control men and women with normal } \\
\text { laryngeal mucosa }\end{array}$ & 84.5 & 14.6 & 0.9 \\
\hline & & 323 & Men and women with laryngeal cancer & 89.2 & 9.9 & 0.9 \\
\hline starska et al., 2014 (৪1) & Polisn & 418 & Control healthy men and women & 84.0 & 16.0 & 0.0 \\
\hline Krześlak et al., 2014 & Polish & 534 & Women with ductal breast cancer & 87.1 & 12.3 & 0.6 \\
\hline & Ponsn & 556 & Control healthy women & 92.8 & 7.2 & 0.0 \\
\hline Krześlak et al., 2013 & & 412 & Men with prostate cancer & 76.0 & 21.1 & 2.9 \\
\hline (86) & Polisn & 67 & Control men without prostate cancer & 88.0 & 12.0 & 0.0 \\
\hline Wang et al., 2012 (106) & US & 239 & Men and women & 89.1 & 10.1 & 0.8 \\
\hline Forma et al 2012 (87) & Polich & 358 & Men with prostate cancer & 76.8 & 20.9 & 2.3 \\
\hline Fomाa et al., $2012(0 /)$ & Polisn & 406 & Control men without prostate cancer & 88.9 & 10.6 & 0.5 \\
\hline Tekin et al., 2012 (89) & Turkish & 95 & Mother-newborn pairs & 87.4 & 12.6 & 0.0 \\
\hline Tekin et al., 2012 (90) & Turkish & 91 & Mother-newborn pairs & 86.8 & 13.2 & 0.0 \\
\hline Kayaalti et al., 2011 (91) & Turkish & 616 & Men and women & 86.6 & 12.8 & 0.6 \\
\hline Kayaalti et al., 2011 (92) & Turkish & 354 & Men and women & 90.4 & 9.0 & 0.6 \\
\hline McElroy et al., 2010 & US & 142 & Black women & 97.9 & 2.1 & - \\
\hline (98) & Un & 149 & White women & 87.3 & 12.8 & - \\
\hline Kayaalti et al., 2010 & Turkish & 122 & Men and women (kidney samples) & 88.5 & 10.7 & 0.8 \\
\hline & IUIKISII & 186 & Men and women (blood samples) & 86.0 & 13.4 & 0.6 \\
\hline Kayaalti et al., 2010 (94) & Turkish & 114 & Men and women (kidney samples) & 87.7 & 11.4 & 0.9 \\
\hline Hayashi et al., 2006 & & 37 & Patients with SALS & 75.7 & 24.3 & 0.0 \\
\hline (96) & Japanese & 206 & Control healthy men and women & 82.5 & 17.0 & 0.5 \\
\hline
\end{tabular}

n-sample size; AA - typical homozygote; AG - heterozygote; GG - atypical homozygote; AMD - age-related macular degeneration; SIP - sinonasal inverted papilloma (Schneiderian papilloma); SCC - squamous cell laryngeal carcinoma; SALS - sporadic amyotrophic lateral sclerosis; ${ }^{*}$ A allele frequency; ${ }^{\circledR} \mathrm{G}$ allele frequency; ${ }^{\S} \mathrm{G}$ allele carriers (AG plus GG genotype) 


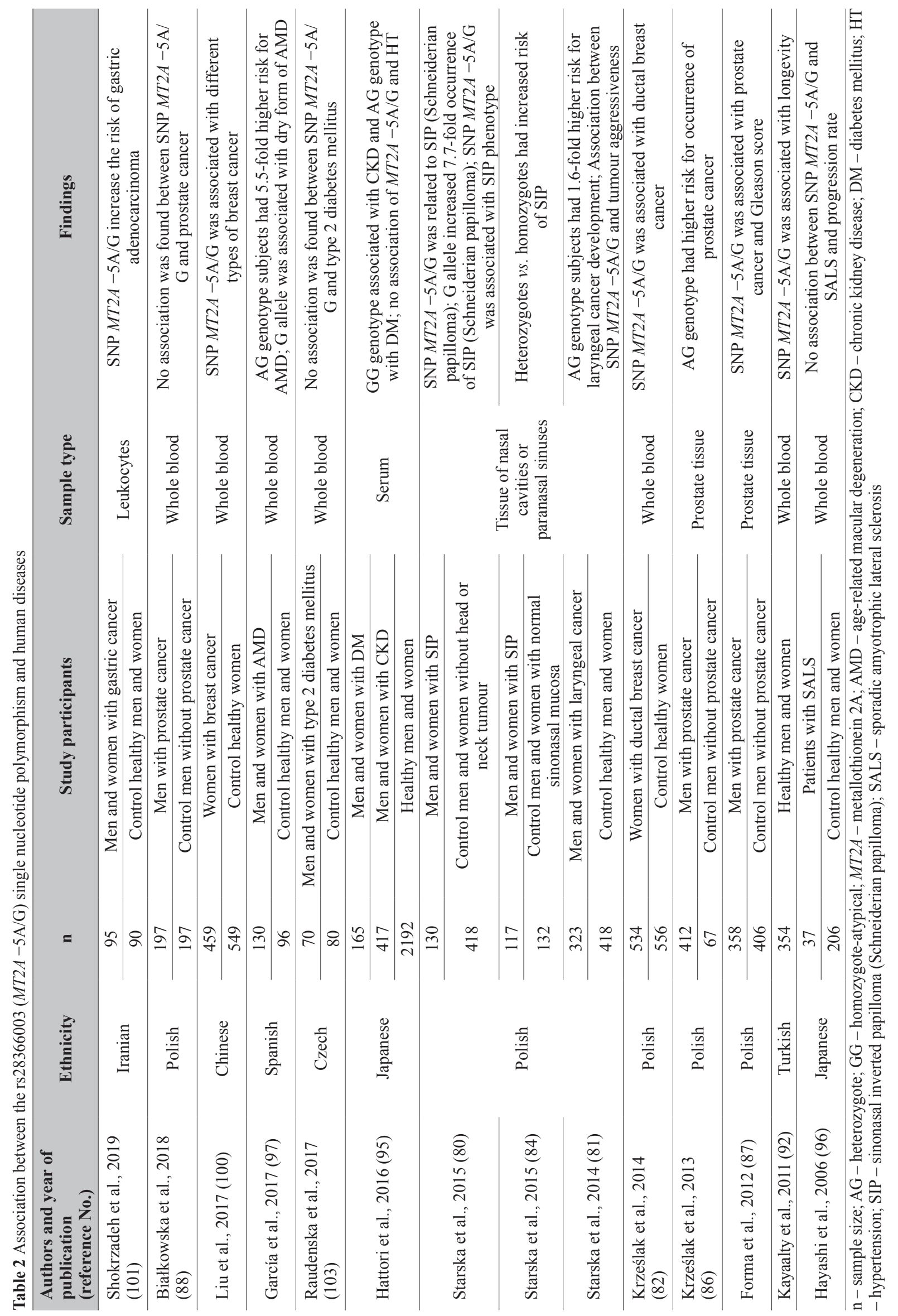




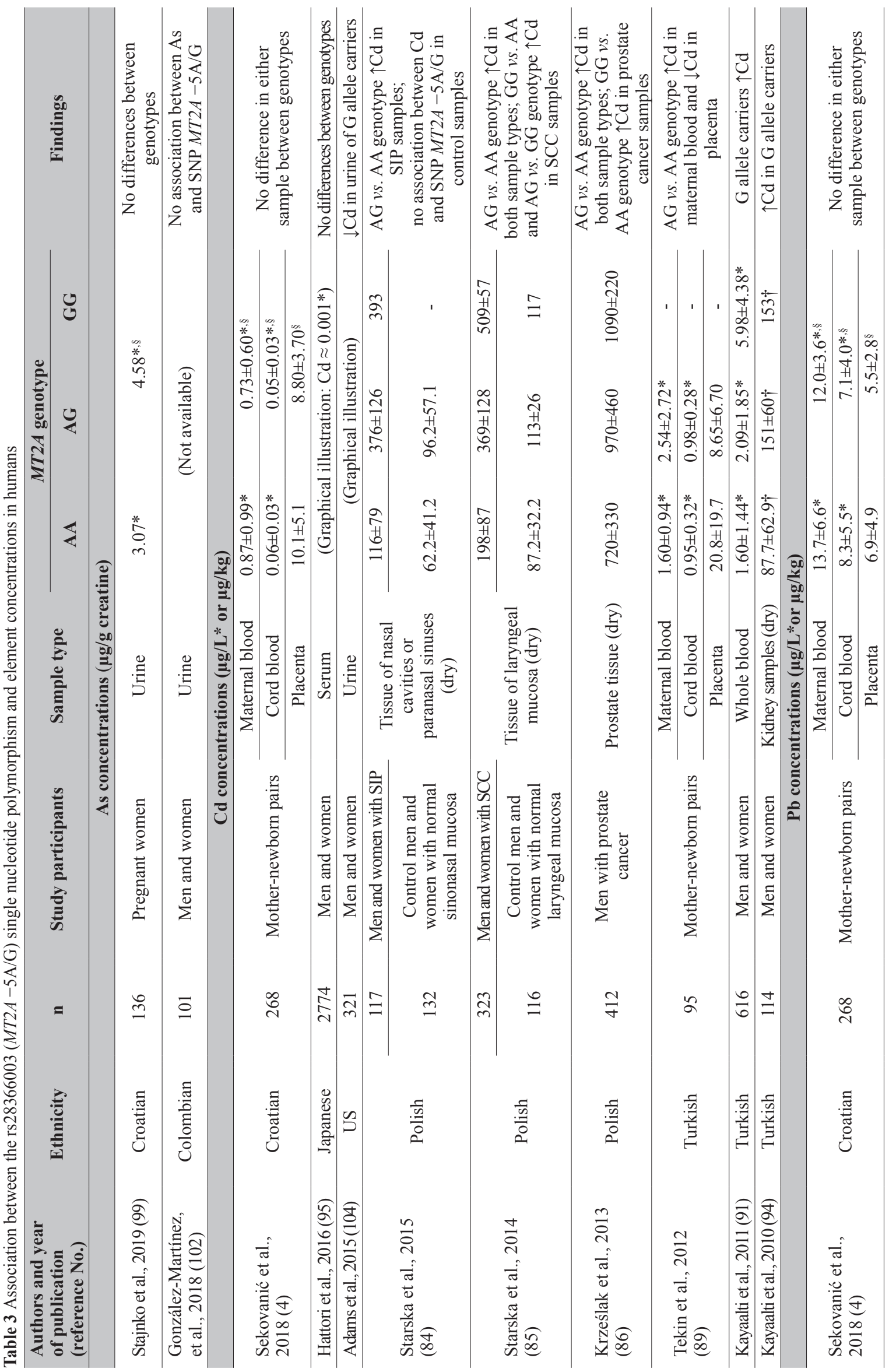




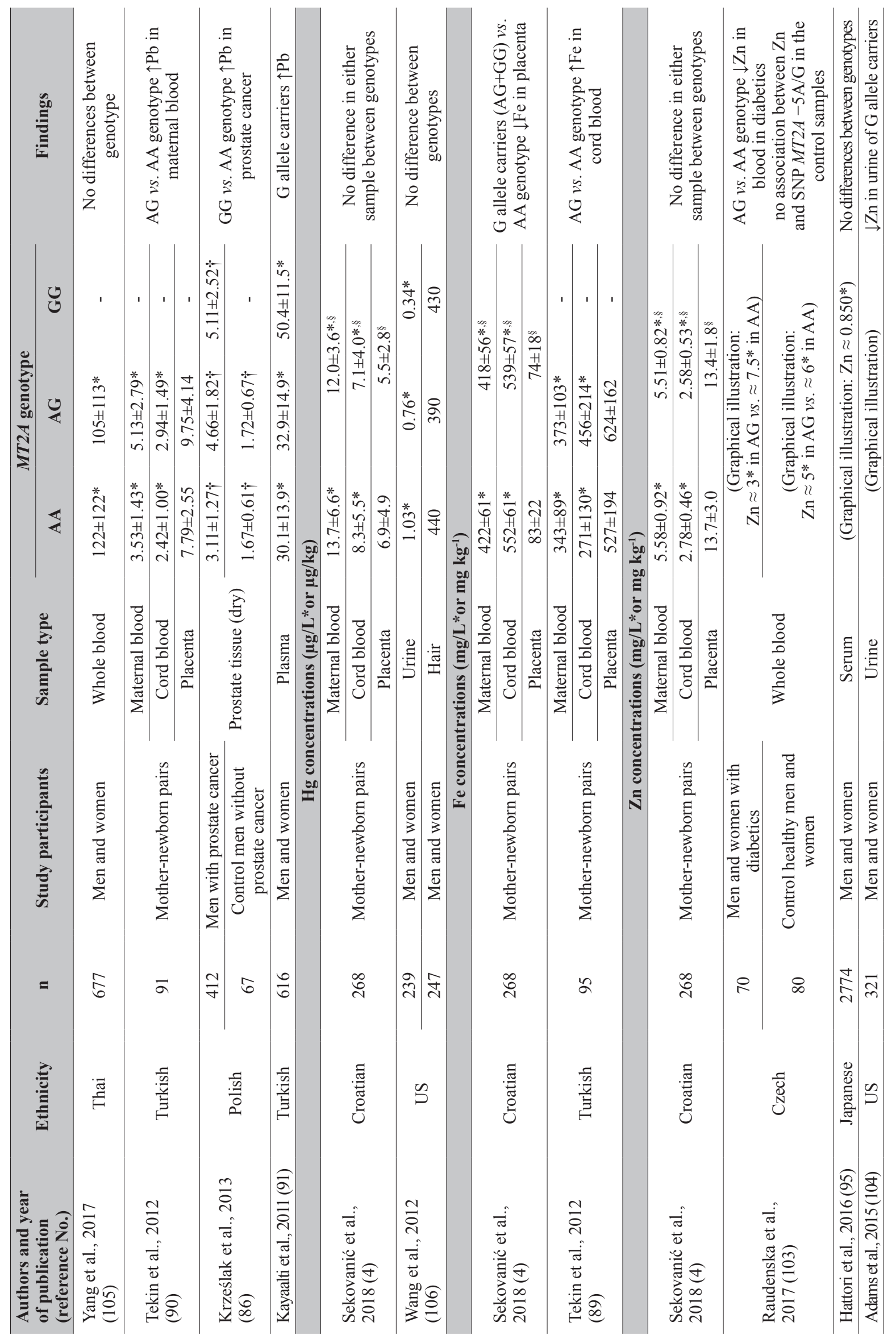




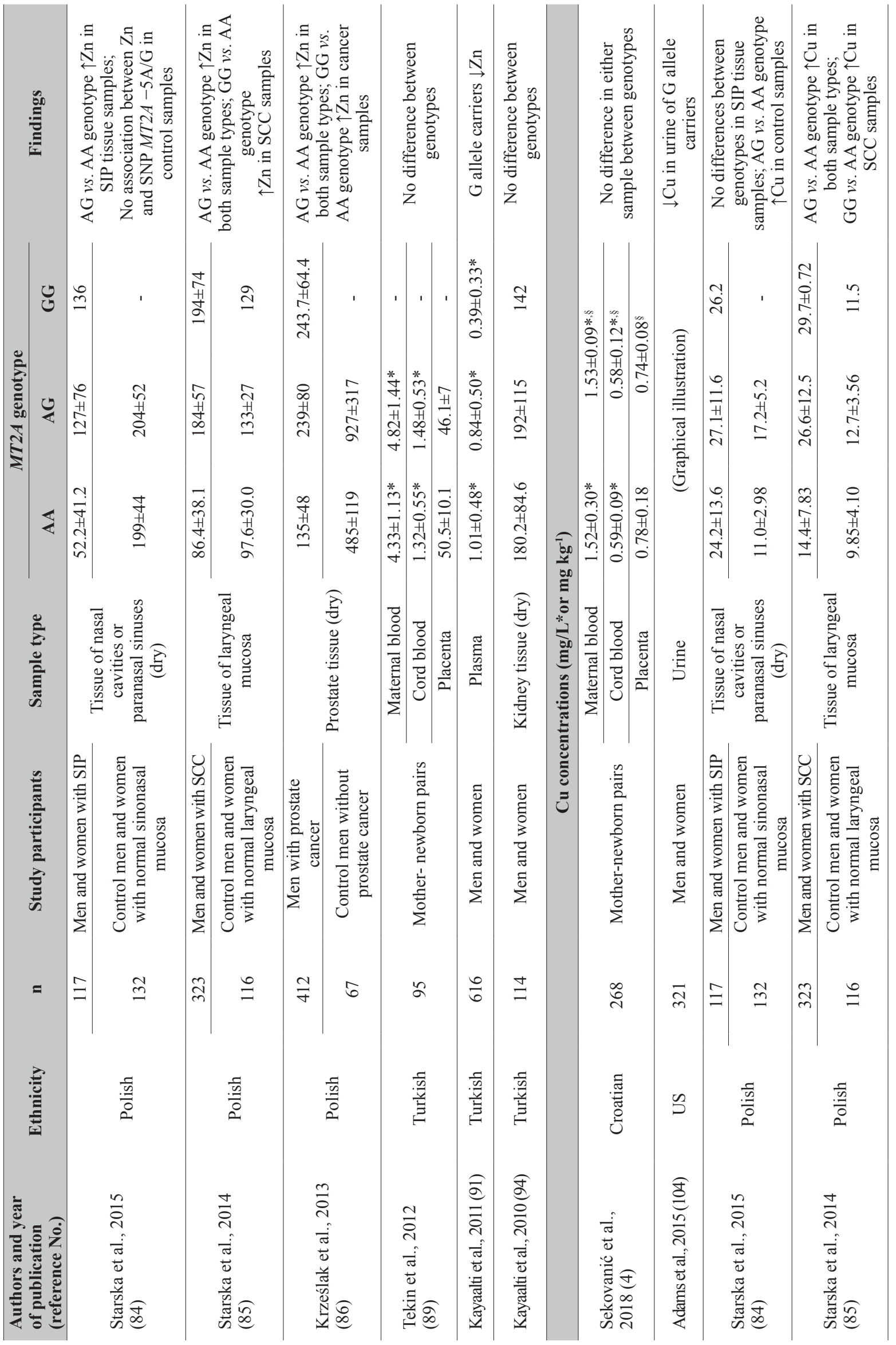




\section{MT2A rs 1610216 polymorphism}

The rs1610216 (MT2A -209A/G) SNP also occurs in the promoter region. Unlike rs28366003, however it has received considerably less attention and most of the studies were done in Polish population. Table 4 summarises its genotype frequencies. The frequencies of the $\mathrm{AA}, \mathrm{AG}$, and GG genotype in healthy Polish population ranged from $72.0 \%$ to $73.9 \%, 25.3 \%$ to 27.8 , and $0.2 \%$ to $0.8 \%$, respectively $(80-82,87)$. Similar AA genotype frequencies were reported for healthy Italian population, while their GG genotype frequencies were somewhat higher, from $3.0 \%$ to $3.7 \%(112,113)$. The highest AA genotype frequency of $90.5 \%$ was reported in healthy Bulgarian population (114). The same study also reported higher percentage of the AG genotype in patients with type 2 diabetes mellitus and coronary artery disease than in healthy persons.

Table 5 shows the association between MT2A rs 1610216 and human diseases. Studies conducted in Polish population found no association between rs1610216 and either Schneiderian papilloma or laryngeal cancer $(80,81)$. No associations were also reported for this SNP and breast or prostate cancers $(82,87)$, carotid artery stenosis and hypertension $(112,113)$, or coronary artery disease (114). Positive association was reported with type 2 diabetes mellitus (114) and subjects with the AA genotype ran a higher risk of ischaemic cardiomyopathy and hyperglycaemia (112). There are no data on association between the rs1610216 SNP and element concentrations in human organism, except the one study (112) dealing with an association between this SNP and $\mathrm{Zn}$ in plasma (Table 6).

\section{MT2A rs 10636 polymorphism}

The rs10636 (MT2A +838G/C) SNP occurs in the 3'UTR. Genotype frequencies of this SNP are presented in Table 7. The frequencies of the GG genotype range from $42.9 \%$ in Chinese (115) to $67.7 \%$ in healthy Spanish population (97). Healthy Chinese population had the highest percentage of the CC genotype (9.7\%) (115), whereas the US and Polish populations had the lowest frequency (about $4.0 \%)(82,104)$. The only study that reported genotype frequencies of the rs 10636 SNP in children was in boys and girls with the mean age of 10 years in Portugal, a country known for increased Hg intake through seafood/fish consumption and the risk of related neurotoxic effects in both sexes at young age (116).

Table 8 summarises the findings on associations between rs 10636 and diseases. This polymorphism may be associated with higher incidence of neuropathy and hyperlipidaemia in patients with type 2 diabetes mellitus (115), coronary heart disease (117), and breast cancer (100). Krześlak et al. (82) found no association with ductal breast cancer. No association was also reported between rs 10636 and macular degeneration related to age (97), Schneiderian papilloma, or laryngeal cancer $(80,81)$. Giacconi et al. (113) 
Table 4 Genotype frequencies of the rs1610216 (MT2A -209A/G) single nucleotide polymorphism in humans

\begin{tabular}{|c|c|c|c|c|c|c|}
\hline \multirow{2}{*}{$\begin{array}{l}\text { Authors and year } \\
\text { of publication } \\
\text { (reference No.) }\end{array}$} & \multirow{2}{*}{ Ethnicity } & \multirow[b]{2}{*}{$\mathbf{n}$} & \multirow{2}{*}{ Study population } & \multicolumn{3}{|c|}{ Genotype frequencies (\%) } \\
\hline & & & & $\mathbf{A A}$ & AG & GG \\
\hline \multirow{2}{*}{$\begin{array}{l}\text { Starska et al., } 2015 \\
(80)\end{array}$} & \multirow[b]{2}{*}{ Polish } & 130 & Men and women with SIP & 73.8 & 25.4 & 0.8 \\
\hline & & 418 & $\begin{array}{l}\text { Control men and women without head } \\
\text { and neck tumours }\end{array}$ & 73.9 & 25.3 & 0.8 \\
\hline \multirow{2}{*}{$\begin{array}{l}\text { Starska et al., } 2014 \\
(81)\end{array}$} & \multirow{2}{*}{ Polish } & 323 & Men and women with laryngeal cancer & 73.4 & 26.0 & 0.6 \\
\hline & & 418 & Control healthy men and women & 73.9 & 25.3 & 0.8 \\
\hline \multirow{2}{*}{$\begin{array}{l}\text { Krześlak et al., } \\
2014(82)\end{array}$} & \multirow{2}{*}{ Polish } & 534 & Women with breast cancer & 76.4 & 23.4 & 0.2 \\
\hline & & 556 & Control healthy women & 72.3 & 27.5 & 0.2 \\
\hline \multirow{2}{*}{$\begin{array}{l}\text { Forma et al., } 2012 \\
\text { (87) }\end{array}$} & \multirow{2}{*}{ Polish } & 358 & Men with prostate cancer & 71.8 & 27.6 & 0.6 \\
\hline & & 406 & Control men without prostate cancer & 72.0 & 27.8 & 0.2 \\
\hline \multirow{3}{*}{$\begin{array}{l}\text { Kozarova et al., } \\
2012(114)\end{array}$} & \multirow{3}{*}{ Bulgarian } & 142 & Patients with CAD & 89.2 & 9.4 & 1.4 \\
\hline & & 101 & Patients with DM & 69.7 & 28.3 & 2.0 \\
\hline & & 61 & Control healthy volunteers & 90.5 & 0.0 & 9.5 \\
\hline \multirow{3}{*}{$\begin{array}{l}\text { Giacconi et al., } \\
2007 \text { (113) }\end{array}$} & \multirow{3}{*}{ Italian } & 100 & CS patients & 75.0 & 24.0 & 1.0 \\
\hline & & 188 & $\begin{array}{c}\text { CS patients without cerebrovascular } \\
\text { episodes }\end{array}$ & 73.0 & 25.0 & 2.0 \\
\hline & & 218 & Control elderly volunteers & 71.0 & 26.0 & 3.0 \\
\hline \multirow{2}{*}{$\begin{array}{l}\text { Giacconi et al., } \\
2005 \text { (112) }\end{array}$} & \multirow{2}{*}{ Italian } & 91 & Men and women with carotid stenosis & 86.0 & 14.0 & 0.0 \\
\hline & & 188 & Control elderly men and women & 70.2 & 26.1 & 3.7 \\
\hline
\end{tabular}

n - sample size; AA - typical homozygote; AG - heterozygote; GG - atypical homozygote; SIP - sinonasal inverted papilloma (Schneiderian papilloma); CAD - coronary artery disease; DM - diabetes mellitus; CS - carotid artery stenosis

reported that in the $\mathrm{C}$ allele carriers carotid artery disease was more likely to progress to carotid artery stenosis.

The associations between this polymorphism and element concentrations in human organism are presented in Table 9. A weak association was reported for blood $\mathrm{Cd}$ in healthy women exposed to $\mathrm{Cd}$ (118). Although $\mathrm{Hg}$ was not associated with the $\mathrm{CC}$ genotype, a multivariate analysis indicated lower $\mathrm{Hg}$ in urine in subjects with the $\mathrm{CC}$ genotype than those with the GG genotype (106). C allele carriers were found to have lower concentrations of $\mathrm{Cd}, \mathrm{Cu}$ and $\mathrm{Zn}$ in urine (104), $\mathrm{Pb}$ in blood $(119,120)$, and $\mathrm{Fe}$ in plasma (113) and higher $\mathrm{Zn}$ and $\mathrm{Cu}$ in red blood cells (113).

\section{CONCLUDING REMARKS}

There is strong evidence that MTs participate in physiological and pathological processes in the human body which involve the homeostasis of intracellular essential element, primarily $\mathrm{Zn}$ and $\mathrm{Cu}$. They may chelate divalent toxic metals, such as $\mathrm{Cd}, \mathrm{Pb}, \mathrm{Hg}$, or Pt with the -SH groups in cysteine and thus detoxify cells, scavenge free radicals, and protect cells against oxidative stress. They also have a role in cell survival and proliferation, angiogenesis, and inhibition of apoptosis. Emerging evidence confirms that MT insufficiency may lead to pathogenic processes and carcinogenesis. Single gene polymorphisms of MTs may be responsible for individual differences in reactions to harmful effects of external chemical and physical stressors and reactive oxygen species in the body.
Identification of individual MT isoforms in human cells and tissues can be applied in prospective tissue, plasma, and urine analyses or retrospectively, using fixed paraffinembedded tissue samples. In the future, MTs may serve as biomarkers of environmental exposure to toxic metals, such as $\mathrm{Cd}$, as already reported in biomonitoring studies on occupational exposure in humans (121-123) or environmental exposure in animals (124-126). MTs are also intensively studied as potential clinical biomarkers to be used in the diagnosis, prognosis, and selection of efficient therapy/ies for a number of malignant tumours, such as breast, thyroid, head, neck, lung, gallbladder, pancreas, colon, kidney, ovary, prostate, bone, and skin cancers, childhood solid tumours, and various types of leukaemia (29-32, 82, 86, 87, 94, 127-132). Exogenous MTs are already being investigated for the treatment of pathological processes in the central nervous system (59).

To date, the rs28366003, rs10636, and rs1610216 SNPs in the $M T 2 A$ gene have been associated with various physiological and pathological conditions. These involve ageing and chronic diseases, such as metabolic syndrome (including type 2 diabetes mellitus and obesity), cardiovascular diseases, osteoporosis, and psychiatric disorders. They also seem to interfere with the effects of toxic drugs and pollutants. However, their use as risk predictors remains controversial. Identifying a single specific allelic variant associated with an individual trait, health or disease by gene-specific, candidate-driven studies (133) may fail to provide full information and risk assessment of certain diseases, which, as a rule, have 


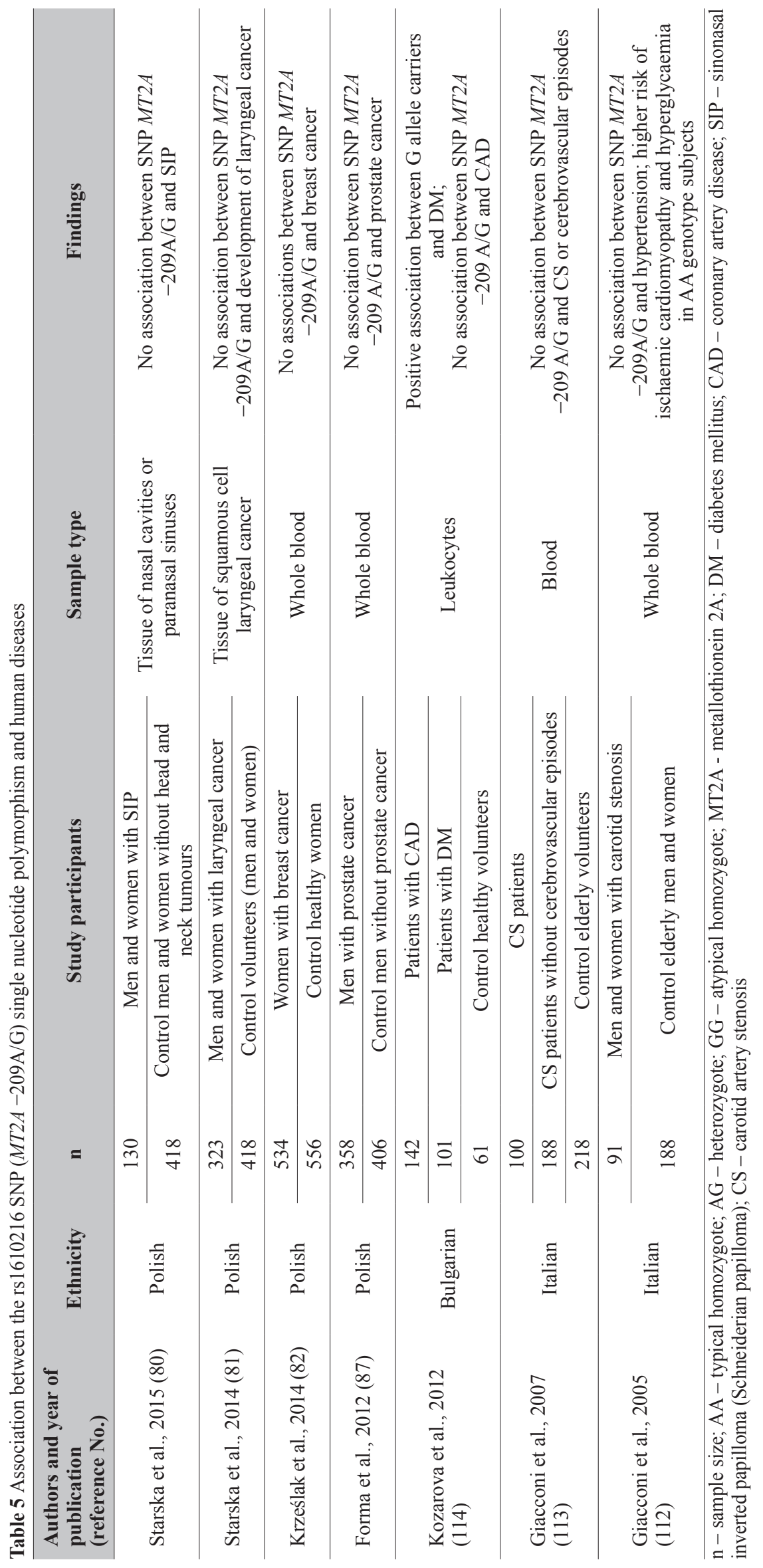




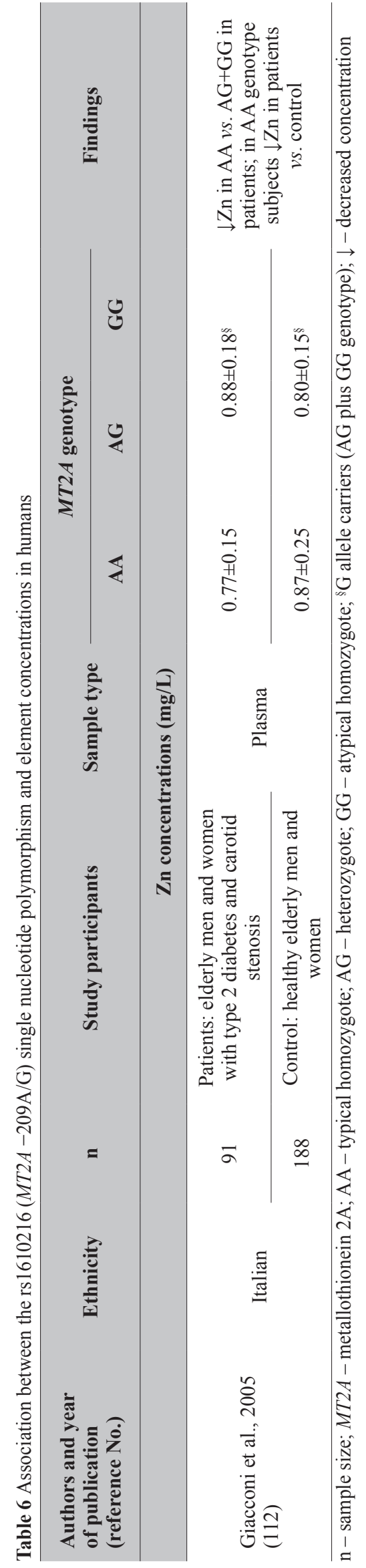

polygenic origins $(134,135)$ and therefore need genomewide association studies $(136,137)$. More comprehensive studies are needed to determine the role and potential for the clinical use of specific $M T 2 A$ gene polymorphisms. These should recruit a large number of participants (several hundreds and more) with well-defined pathological process and take into account other factors and risks, such as specific environmental exposure and personal habits, genetic characteristics, and epigenetic makeup.

\section{Conflict of interests}

None to declare.

\section{Acknowledgement}

Financial support for this work started during the research project "Exposure to metals and their effects in pregnancy and postnatal period" (Croatian Ministry of Science, Education and Sports' grant 022-0222148-2135) and continued through the research project "Assessment of Daily Exposure to Metals and Maternal Individual Susceptibility as Factors of Developmental Origins of Health and Disease, METALORIGINS" (Croatian Science Foundation grant HRZZ-IP-2016-06-1998).

\section{REFERENCES}

1. Landrigan PJ, Fuller R, Hu H, Caravanos J, Cropper ML, Hanrahan D, Sandilya K, Chiles TC, Kumar P, Suk WA. Pollution and global health - An agenda for prevention. Environ Health Perspect 2018;126:084501. doi: 10.1289/ EHP3141

2. Schwartz DA, Weis B, Wilson SH. The need for exposure health sciences. Environ Health Perspect 2005;113:A650. doi: 10.1289/ehp.113-1281298

3. Sexton K, Hattis D. Assessing cumulative health risks from exposure to environmental mixtures - Three fundamental questions. Environ Health Perspect 2007;115:825-32. doi: 10.1289/ehp. 9333

4. Sekovanić A, Jurasović J, Piasek M, Pašalić D, Orct T, Grgec AS, Stasenko S, Čakanić KB, Jazbec A. Metallothionein $2 \mathrm{~A}$ gene polymorphism and trace elements in mother-newborn pairs in the Croatian population. J Trace Elem Med Biol 2018;45:163-70. doi: 10.1016/j.jtemb.2017.10.011

5. Vallee BL. Metallothionein: historical review and perspectives. In: Kagi JHR, Norberg M, editors. Metallothionein. Experientia supplementum 34 / FEBS Symposia Series 59. Basel: Birkhäuser; 1979. p. 19-38. doi: 10.1007/978-3-0348-6493-0_1

6. Nordberg M. Metallothioneins: historical review and state of knowledge. Talanta 1998;46:243-54. doi: 10.1016/s00399140(97)00345-7

7. Capdevila M, Bofill R, Palacios Ò, Atrian S. State-of-the-art of metallothioneins at the beginning of the $21^{\text {st }}$ century. Coordin Chem Rev 2012;256:46-62. doi: 10.1016/j. ccr.2011.07.006

8. Waalkes MP, Pérez-Ollé R. Role of metallothionein in the metabolism, transport and toxicity of metals. In: Zalups RK, Koropatnick J, editors. Molecular biology and toxicology of 
Table 7 Genotype frequencies of the rs $10636(M T 2 A+838 \mathrm{G} / \mathrm{C})$ single nucleotide polymorphism in humans

\begin{tabular}{|c|c|c|c|c|c|c|}
\hline \multirow{2}{*}{$\begin{array}{l}\text { Authors and year } \\
\text { of publication } \\
\text { (reference No.) }\end{array}$} & \multirow{2}{*}{ Ethnicity } & \multirow{2}{*}{$\mathbf{n}$} & \multirow{2}{*}{ Study participants } & \multicolumn{3}{|c|}{ Genotype frequencies (\%) } \\
\hline & & & & GG & GC & $\mathrm{CC}$ \\
\hline Yang et al., 2017 (105) & Thai & 677 & Men and women & 52.4 & 41.6 & 6.0 \\
\hline \multirow{2}{*}{ Liu et al., 2017 (100) } & \multirow{2}{*}{ Chinese } & 459 & Women with breast cancer & 52.5 & 37.5 & 11.8 \\
\hline & & 549 & Control healthy women & 52.8 & 40.8 & 6.4 \\
\hline \multirow{2}{*}{$\begin{array}{l}\text { García et al., } 2017 \\
\text { (97) }\end{array}$} & \multirow{2}{*}{ Spanish } & 130 & Men and women with AMD & 56.9 & 36.9 & 6.2 \\
\hline & & 96 & Control healthy men and women & 67.7 & 27.1 & 5.2 \\
\hline $\begin{array}{l}\text { Fernandes et al., } 2016 \\
\text { (119) }\end{array}$ & Brazilian & 221 & Workers in car battery factories & 62.0 & 32.0 & 6.0 \\
\hline \multirow{2}{*}{$\begin{array}{l}\text { Adams et al., } 2015 \\
\text { (104) }\end{array}$} & \multirow{2}{*}{ US } & 170 & Premenopausal women & 54.0 & 42.0 & 4.0 \\
\hline & & 151 & Men and women & 62.0 & 34.0 & 4.0 \\
\hline \multirow{2}{*}{$\begin{array}{l}\text { Starska et al., } 2015 \\
(80)\end{array}$} & \multirow[b]{2}{*}{ Polish } & 130 & Men and women with SIP & 44.6 & 43.1 & 12.3 \\
\hline & & 418 & $\begin{array}{l}\text { Control men and women without } \\
\text { head and neck tumours }\end{array}$ & 50.9 & 41.2 & 7.9 \\
\hline \multirow{2}{*}{$\begin{array}{l}\text { Starska et al., } 2014 \\
(81)\end{array}$} & \multirow{2}{*}{ Polish } & 323 & Men and women with laryngeal cancer & 45.8 & 46.1 & 8.1 \\
\hline & & 418 & Control volunteers (men and women) & 50.9 & 41.2 & 7.9 \\
\hline \multirow{2}{*}{$\begin{array}{l}\text { Yang et al., } 2014 \\
\text { (117) }\end{array}$} & \multirow{2}{*}{ Chinese } & 287 & Men and women with CHD & 46.0 & 45.3 & 8.7 \\
\hline & & 226 & Control healthy men and women & 57.1 & 36.7 & 6.2 \\
\hline \multirow{2}{*}{$\begin{array}{l}\text { Krześlak et al., } 2014 \\
\text { (82) }\end{array}$} & \multirow{2}{*}{ Polish } & 534 & Women with breast cancer & 57.1 & 38.4 & 4.5 \\
\hline & & 556 & Control healthy women & 50.3 & 45.5 & 4.2 \\
\hline \multirow{2}{*}{$\begin{array}{l}\text { Woods et al., } 2013 \\
\text { (116) }\end{array}$} & \multirow{2}{*}{ Portuguese } & 163 & Boys average age 10 years & 61.3 & 30.7 & 8.0 \\
\hline & & 167 & Girls average age 10 years & 59.9 & 33.5 & 6.6 \\
\hline Chen et al., 2012 (118) & Chinese & 465 & Men and women & 52.3 & 39.5 & 8.2 \\
\hline Wang et al., 2012 (106) & US & 464 & Men and women & 54.1 & 36.8 & 9.1 \\
\hline \multirow{2}{*}{$\begin{array}{l}\text { Forma et al., } 2012 \\
\text { (87) }\end{array}$} & \multirow{2}{*}{ Polish } & 358 & Men with prostate cancer & 48.9 & 43.3 & 7.8 \\
\hline & & 406 & Control men without prostate cancer & 52.0 & 40.0 & 8.0 \\
\hline $\begin{array}{l}\text { Gundacker et al., } \\
2009(120)\end{array}$ & Austrian & 180 & Men and women & 58.4 & 33.3 & 8.3 \\
\hline \multirow{2}{*}{$\begin{array}{l}\text { Yang et al., } 2008 \\
(115)\end{array}$} & \multirow{2}{*}{ Chinese } & 182 & Men and women with DM & 46.7 & 42.9 & 10.4 \\
\hline & & 196 & Control volunteers (men and women) & 42.9 & 47.4 & 9.70 \\
\hline \multirow{3}{*}{$\begin{array}{l}\text { Giacconi et al., } 2007 \\
\text { (113) }\end{array}$} & \multirow{3}{*}{ Italian } & 100 & CS patients & 73.0 & 22.0 & 5.0 \\
\hline & & 188 & $\begin{array}{c}\text { CS patients without cerebrovascular } \\
\text { episodes }\end{array}$ & 66.0 & 30.0 & 4.0 \\
\hline & & 218 & Control elderly volunteers & 56.0 & 37.0 & 7.0 \\
\hline
\end{tabular}

n - sample size; $M T 2 A$ - metallothionein 2A; GG - typical homozygote; $\mathrm{GC}$ - heterozygote; $\mathrm{CC}$ - atypical homozygote; AMD - agerelated macular degeneration; SIP - sinonasal inverted papilloma (Schneiderian papilloma); CHD - coronary heart disease; DM diabetes mellitus; $\mathrm{CS}$ - carotid artery stenosis

metals. London and New York: Taylor \& Francis; 2000. p. 414-59.

9. Vašák M, Meloni G. Chemistry and biology of mammalian metallothioneins. J Biol Inorg Chem 2011;16:1067-78. doi: 10.1007/s00775-011-0799-2

10. Cai L, Liu MG, Cherian GM. Metallothionein and intracellular sequestration of metals. In: Guengerich FP, editor. Vol. 4. Biotransformation. Comprehensive toxicology. $2^{\text {nd }}$ ed. Kidlington (UK): Elsevier Ltd.; 2010. p. 501-17.

11. Babula P, Masarik M, Adam V, Eckschlager T, Stiborova M, Trnkova L, Skutkova H, Provaznik I, Hubalek J, Kizek R. Mammalian metallothioneins: properties and functions. Metallomics 2012;4:739-50. doi: 10.1039/c2mt20081c
12. Krężel A, Maret W. The functions of metamorphic metallothioneins in zinc and copper metabolism. Int J Mol Sci 2017;18:1237. doi: 10.3390/ijms 18061237

13. Coyle P, Philcox JC, Carey LC, Rofe AM. Metallothionein: the multipurpose protein. Cell Mol Life Sci 2002;59:627-47. doi: 10.1007/s00018-002-8454-2

14. Kimura T, Kambe T. The functions of metallothionein and ZIP and ZnT transporters: an overview and perspective. Int J Mol Sci 2016;17:336. doi: 10.3390/ijms17030336

15. Dziegiel P, Pula B, Kobierzycki C, Stasiolek M, PodhorskaOkolow M. Metallothioneins: structure and functions. In: Dziegiel P, Pula B, Kobierzycki C, Stasiolek M, PodhorskaOkolow M, editors. Metallothioneins in normal and cancer 


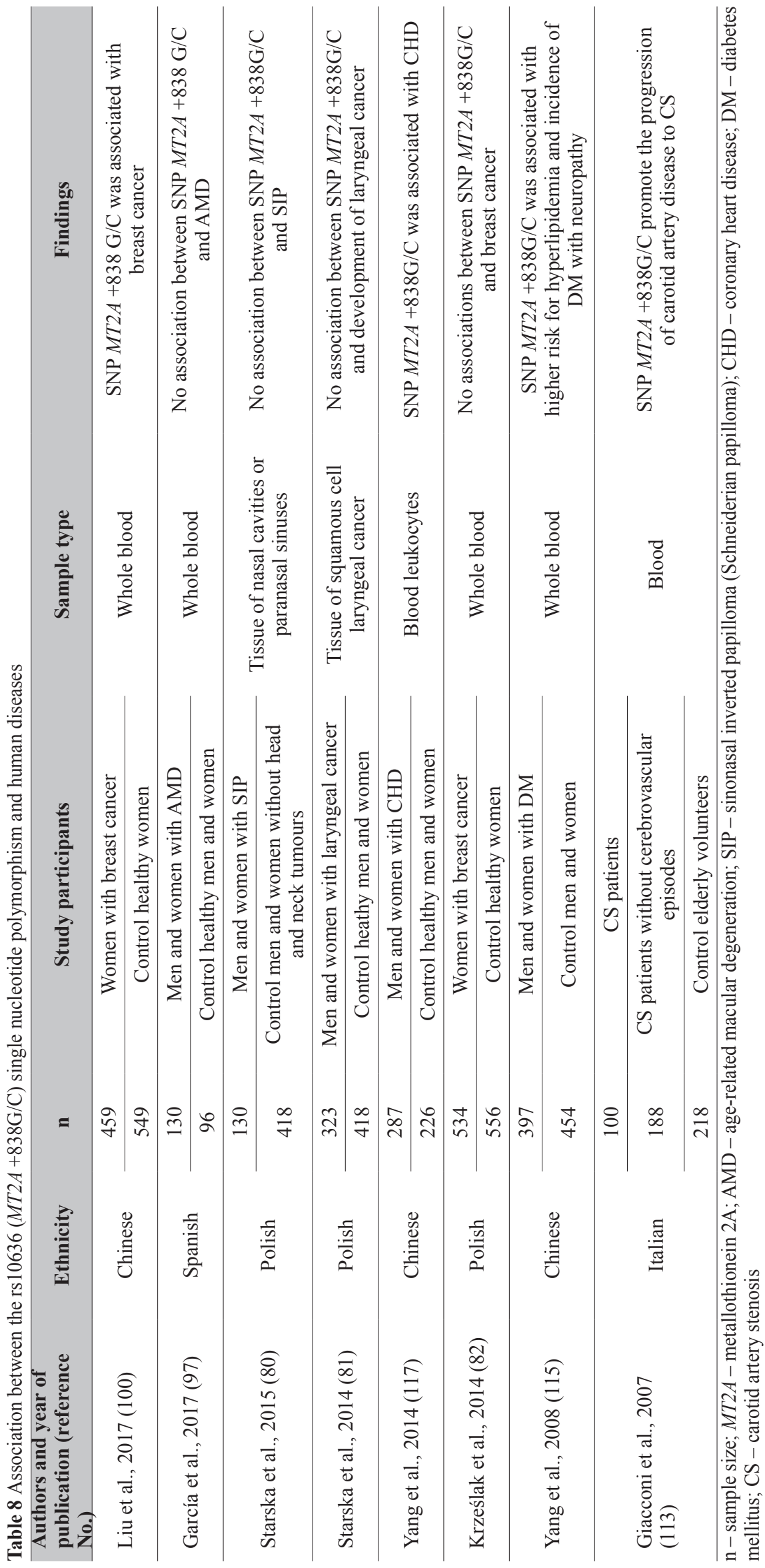




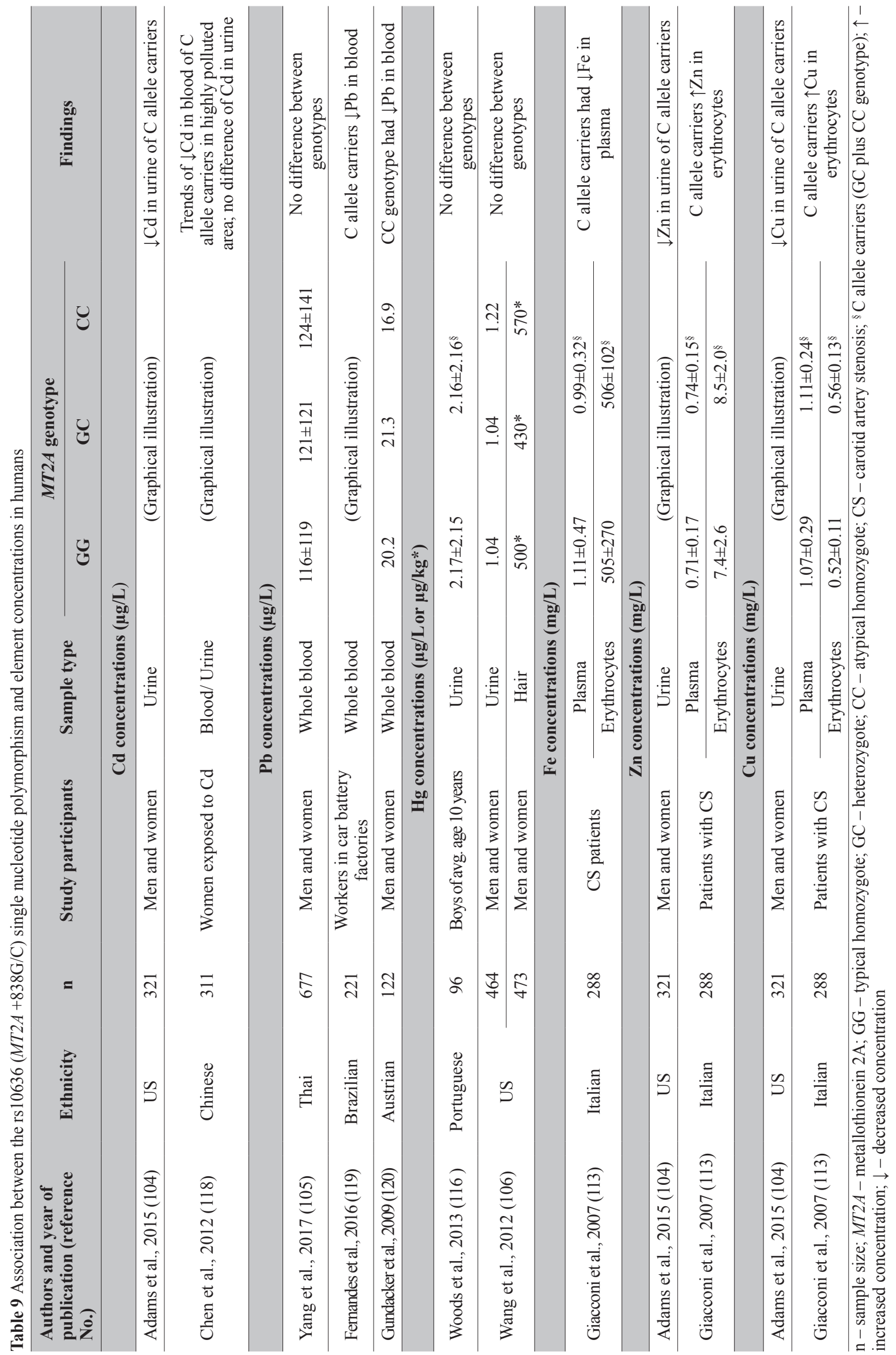


cells. Advances in anatomy, embryology and cell biology. New York/London: Springer; 2016. p. 3-20.

16. Meloni G, Zovo K, Kazantseva J, Palumaa P, Vasák M. Organization and assembly of metal-thiolate clusters in epithelium-specific metallothionein-4. J Biol Chem 2006;281:14588-95. doi: 10.1074/jbc.M601724200

17. Kojima Y, Berger C, Vallee BL, Kägi JH. Amino-acid sequence of equine renal metallothionein-1B. Proc Natl Acad Sci USA 1976;73:3413-7. doi: 10.1073/pnas.73.10.3413

18. Templeton DM, Dean PA, Cherian MG. The reaction of metallothionein with mercuribenzoate. A dialysis and ${ }^{113} \mathrm{Cd}-$ n.m.r. study. Biochem J 1986;234:685-9. doi: 10.1042/ bj 2340685

19. Waalkes MP, Harvey MJ, Klaassen CD. Relative in vitro affinity of hepatic metallothionein for metals. Toxicol Lett 1984;20:33-9. doi: 10.1016/0378-4274(84)90179-6

20. Nielson KB, Winge DR. Independence of the domains of metallothionein in metal binding. J Biol Chem 1985;260:8698701. PMID: 4019449

21. Hamer DH. Metallothionein. Annu Rev Biochem 1986;55:913-51. doi: 10.1146/annurev.bi.55.070186.004405

22. Kägi JHR, Valee BL. Metallothionein: a cadmium- and zinccontaining protein from equine renal cortex. J Biol Chem 1960;235:3460-5. PMID: 13750713

23. Day FA, Funk AE, Brady FO. In vivo and ex vivo displacement of zinc from metallothionein by cadmium and by mercury. Chem Biol Interact 1984;50:159-74. doi: 10.1016/0009-2797(84)90093-0

24. Sabolić I, Breljak D, Škarica M, Herak-Kramberger CM. Role of metallothionein in cadmium traffic and toxicity in kidneys and other mammalian organs. BioMetals 2010;23:897-926. doi: 10.1007/s10534-010-9351-z

25. Kägi JHR, Schäffer A. Biochemistry of metallothionein. Biochemistry 1988;27:8509-15. doi: 10.1021/bi00423a001

26. Klaassen CD, Choudhuri S, McKim JM Jr, LehmanMcKeeman LD, Kershaw WC. In vitro and in vivo studies on the degradation of metallothionein. Environ Health Perspect 1994;102(Suppl 3):141-6. doi: 10.1289/ ehp. $94102 \mathrm{~s} 3141$

27. McKim JM Jr, Choudhuri S, Klaassen $\mathrm{CD}$. In vitro degradation of apo-, zinc-, and cadmium-metallothionein by cathepsins B, C, and D. Toxicol Appl Pharmacol 1992;116:117-24. doi: 10.1016/0041-008x(92)90152-i

28. Yang Y, Maret W, Vallee BL. Differential fluorescence labeling of cysteinyl clusters uncovers high tissue levels of thionein. Proc Natl Acad Sci USA 2001;98:5556-9. doi: 10.1073/pnas. 101123298

29. Eckschlager T, Adam V, Hrabeta J, Figova K, Kizek R. Metallothioneins and cancer. Curr Protein Pept Sci 2009;10:360-75. doi: 10.2174/138920309788922243

30. Krizkova S, Kepinska M, Emri G, Rodrigo MAM, Tmejova K, Nerudova D, Kizek R, Adam V. Microarray analysis of metallothioneins in human diseases - A review. J Pharm Biomed Analysis 2016;117:464-73. doi: 10.1016/j. jpba.2015.09.031

31. Krizkova S, Fabrik I, Adam V, Hrabeta J, Eckschlager T, Kizek R. Metallothionein - a promising tool for cancer diagnostics. Bratisl Lek Listy 2009;110:93-7. PMID: 19408840

32. Si M, Lang J. The roles of metallothioneins in carcinogenesis. J Hematol Oncol 2018;11:107. doi: 10.1186/s13045-0180645-x
33. Carpenè E, Andreani G, Isani G. Metallothionein functions and structural characteristics. J Trace Elem Med Biol 2007;21(Suppl 1):35-9. doi: 10.1016/j.jtemb.2007.09.011

34. Davis JJ, Hill HAO, Kurz A, Jacob C, Maret W, Vallee BL. A scanning tunneling microscopy study of rabbit metallothionein. PhysChemComm 1998;1:12-22. doi: 10.1039/A806057F

35. Richards MP, Cousins RJ. Mammalian zinc homeostasis: requirement for RNA and metallothionein synthesis. Biochem Biophys Res Commun 1975;64:1215-23. doi: 10.1016/0006$291 x(75) 90822-0$

36. Richards MP, Cousins RJ. Metallothionein and its relationship to the metabolism of dietary zinc in rats. J Nutr 1976;106:15919. doi: $10.1093 / \mathrm{jn} / 106.11 .1591$

37. Cousins RJ. Absorption, transport, and hepatic metabolism of copper and zinc: special reference to metallothionein and ceruloplasmin. Physiol Rev 1985;65:238-309. doi: 10.1152/ physrev.1985.65.2.238

38. Kiela PR, Ghishan FK. Physiology of intestinal absorption and secretion. Best Pract Res Clin Gastroenterol 2016;30:14559. doi: 10.1016/j.bpg.2016.02.007

39. Lönnerdal B, Sandberg AS, Sandström B, Kunz C. Inhibitory effects of phytic acid and other inositol phosphates on zinc and calcium absorption in suckling rats. J Nutr 1989;119:2114. doi: $10.1093 / \mathrm{jn} / 119.2 .211$

40. Brewer GJ. Zinc acetate for the treatment of Wilson's disease. Expert Opin Pharmacother 2001;2:1473-7. doi: 10.1517/14656566.2.9.1473

41. Ranucci G, Di Dato F, Spagnuolo MI, Vajro P, Iorio R. Zinc monotherapy is effective in Wilson's disease patients with mild liver disease diagnosed in childhood: a retrospective study. Orphanet J Rare Dis 2014;9:41. doi: 10.1186/17501172-9-41

42. Miles AT, Hawksworth GM, Beattie JH, Rodilla V. Induction, regulation degradation, and biological significance of mammalian metallothioneins. Crit Rev Biochem Mol Biol 2000;35:35-70. doi: 10.1080/10409230091169168

43. McAleer MF, Tuan RS. Metallothionein overexpression in human trophoblastic cells protects against cadmium-induced apoptosis. In Vitro Mol Toxicol 2001;14:25-42. doi: 10.1089/109793301316882522

44. Skutkova H, Babula P, Stiborova M, Eckschlager T, Trnkova L, Provaznik I, Hubalek J, Kizek R, Adam V. Structure, polymorphisms and electrochemistry of mammalian metallothioneins - a review. Int J Electrochem Sci 2012;7:12415-31.

45. Ruttkay-Nedecky B, Nejdl L, Gumulec J, Zitka O, Masarik M, Eckschlager T, Stiborova M, Adam V, Kizek R. The role of metallothionein in oxidative stress. Int J Mol Sci 2013;14:6044-66. doi: 10.3390/ijms14036044

46. Nordberg M, Nordberg GF. Toxicological aspects of metallothionein. Cell Mol Biol 2000;46:451-63. PMID: 10774933

47. Bakka A, Webb M. Metabolism of zinc and copper in the neonate: changes in the concentrations and contents of thionein-bound $\mathrm{Zn}$ and $\mathrm{Cu}$ with age in the livers of the newborn of various mammalian species. Biochem Pharmacol 1981;30:721-5. doi: 10.1016/0006-2952(81)90157-X

48. Nartey NO, Banerjee D, Cherian MG. Immunohistochemical localization of metallothionein in cell nucleus and cytoplasm of fetal human liver and kidney and its changes during 
development. Pathology 1987;19:233-8. doi: 10.3109/00313028709066555

49. Chan HM, Cherian MG. Ontogenic changes in hepatic metallothionein isoforms in prenatal and newborn rats Biochem Cell Biol 1993;71:133-40. doi: 10.1139/093-022

50. Goering PL, Klaassen CD. Tolerance to cadmium-induced hepatotoxicity following cadmium pretreatment. Toxicol Appl Pharmacol 1984;74:308-13. doi: 10.1016/0041008X(84)90283-7

51. Chan HM, Cherian MG. Protective roles of metallothionein and glutathione in hepatotoxicity of cadmium. Toxicology 1992;72:281-90. doi: 10.1016/0300-483X(92)90179-I

52. Klaassen CD, Liu J, Diwan BA. Metallothionein protection of cadmium toxicity. Toxicol Appl Pharmacol 2009;238:21520. doi: 10.1016/j.taap.2009.03.026

53. Freisinger $\mathrm{E}$, Vašák $\mathrm{M}$. Cadmium in metallothioneins. In: Sigel A, Sigel H, Sigel RKO, editors. Cadmium: from toxicity to essentiality. Metal ions in life sciences. Vol. 11. Dordrect: Springer; 2013. p. 339-71. doi: 10.1007/978-94-007-5179$8 \_11$

54. Thornalley PJ, Vašák M. Possible role for metallothionein in protection against radiation-induced oxidative stress. Kinetics and mechanism of its reaction with superoxide and hydroxyl radicals. Biochim Biophys Acta 1985;827:36-44. doi: 10.1016/0167-4838(85)90098-6

55. Sato M, Bremner I. Oxygen free radicals and metallothionein. Free Radic Biol Med 1993;14:325-37. doi: 10.1016/08915849(93)90029-T

56. Zangger K, Öz G, Haslinger E, Kunert O, Armitage IM. Nitric oxide selectively releases metals from the amino-terminal domain of metallothioneins: potential role at inflammatory sites. FASEB J 2001;15:1303-5. doi: 10.1096/fj.00-0641fje

57. Zhu J, Meeusen J, Krezoski S, Petering DH. Reactivity of $\mathrm{Zn}-, \mathrm{Cd}-$, and apo-metallothionein with nitric oxide compounds: in vitro and cellular comparison. Chem Res Toxicol 2010;23:422-31. doi: 10.1021/tx900387k

58. Ma H, Su L, Yue H, Yin X, Zhao J, Zhang S, Kung H, Xu Z, Miao J. HMBOX1 interacts with MT2A to regulate autophagy and apoptosis in vascular endothelial cells. Sci Rep 2015;5:15121. doi: 10.1038/srep15121

59. Stankovic RK, Chung RS, Penkowa M. Metallothioneins I and II: neuroprotective significance during CNS pathology. Int J Biochem Cell Biol 2007;39:484-9. doi: 10.1016/j. biocel.2006.09.010

60. Rofe AM, Barry EF, Shelton TL, Philcox JC, Coyle P. Paracetamol hepatotoxicity in metallothionein-null mice. Toxicology 1998;125:131-40. doi: 10.1016/s0300483x(97)00172-8

61. Liu J, Liu Y, Hartley D, Klaassen CD, Shehin-Johnson SE, Lucas A, Cohen SD. Metallothionein-I/II knockout mice are sensitive to acetaminophen-induced hepatotoxicity. J Pharmacol Exp Ther 1999;289:547-52. doi: 10.1007/978-30348-8847-9 81

62. Reeve VE, Nishimura N, Bosnic M, Michalska AE, Choo KHA. Lack of metallothionein-I and -II exacerbates the immunosuppressive effect of ultraviolet $\mathrm{B}$ radiation and cisurocanic acid in mice. Immunology 2000;100:399-404. doi: 10.1046/j.1365-2567.2000.00026.x

63. Hanada K. Photoprotective role of metallothionein in UVinjury - metallothionein-null mouse exhibits reduced tolerance against ultraviolet-B. J Dermatol Sci 2000;23(Suppl 1):S51-6. doi: 10.1016/S0923-1811(99)00078-X
64. Andrews GK. Regulation of metallothionein gene expression by oxidative stress and metal ions. Biochem Pharmacol 2000;59:95-104. doi: 10.1016/S0006-2952(99)00301-9

65. Sato M, Kondoh M. Recent studies on metallothionein: protection against toxicity of heavy metals and oxygen free radicals. Tohoku J Exp Med 2002;196:9-22. doi: 10.1620/ tjem.196.9

66. Karin M, Eddy RL, Henry WM, Haley LL, Byers MG, Shows TB. Human metallothionein genes are clustered on chromosome 16. Proc Natl Acad Sci USA 1984;81:5494-8. doi: 10.1073/pnas.81.17.5494

67. Raudenska M, Gumulec J, Podlaha O, Sztalmachova M, Babula P, Eckschlager T, Adam V, Kizek R, Masarik M. Metallothionein polymorphisms in pathological processes. Metallomics 2014;6:55-68. doi: 10.1039/c3mt00132f

68. Suzuki K, Koizumi S. Individual metal responsive elements of the human metallothionein-IIA gene independently mediate responses to various heavy metal signals. Ind Health 2000;38:87-90. doi: 10.2486/indhealth.38.87

69. Andersen RD, Taplitz SJ, Wong S, Bristol G, Larkin B, Herschman HR. Metal-dependent binding of a factor in vivo to the metal-responsive elements of the metallothionein 1 gene promoter. Mol Cell Biol 1987;7:3574-81. doi: 10.1128/ MCB.7.10.3574

70. Brugnera E, Georgiev O, Radtke F, Heuchel R, Baker E, Sutherland GR, Schaffner W. Cloning, chromosomal mapping and characterization of the human metal-regulatory transcription factor MTF-1. Nucleic Acids Res 1994;22:316773. doi: $10.1093 / \mathrm{nar} / 22.15 .3167$

71. Palmiter RD. Regulation of metallothionein genes by heavy metals appears to be mediated by a zinc-sensitive inhibitor that interacts with a constitutively active transcription factor, MTF-1. Proc Natl Acad Sci USA 1994;91:1219-23. doi: 10.1073/pnas.91.4.1219

72. Otsuka F, Iwamatsu A, Suzuki K, Ohsawa M, Hamer DH, Koizumi S. Purification and characterization of a protein that binds to metal responsive elements of the human metallothionein IIA gene. J Biol Chem 1994;269:23700-7. PMID: 8089141

73. Davidson T, Ke Q, Costa M. Selected molecular mechanisms of metal toxicity and carcinogenicity. In: Nordberg GF, Fowler BA, Nordberg M, editors. Handbook on the toxicology of metals. $4^{\text {th }}$ ed. New York: Academic Press; 2015. p. 173-96.

74. Davis SR, Cousins RJ. Metallothionein expression in animals: a physiological perspective on function. J Nutr 2000;130:1085-8. doi: 10.1093/jn/130.5.1085

75. Kojima I, Tanaka T, Inagi R, Nishi H, Aburatani H, Kato H, Miyata T, Fujita T, Nangaku M. Metallothionein is upregulated by hypoxia and stabilizes hypoxia-inducible factor in the kidney. Kidney Int 2009;75:268-77. doi: 10.1038/ki.2008.488

76. Eibl JK, Abdallah Z, Ross GM. Zinc-metallothionein: a potential mediator of antioxidant defence mechanisms in response to dopamine-induced stress. Can J Physiol Pharmacol 2010;88:305-12. doi: 10.1139/Y10-022

77. Park YH, Lee YM, Kim DS, Park J, Suk K, Kim JK, Han HS. Hypothermia enhances induction of protective protein metallothionein under ischemia. J Neuroinflammation 2013;10:21. doi: 10.1186/1742-2094-10-21 
78. Collins FS, Brooks LD, Chakravarti A. ADNA polymorphism discovery resource for research on human genetic variation. Genome Res 1998;8:1229-31. doi: 10.1101/gr.8.12.1229

79. Sherry ST, Ward M-H, Kholodov M, Baker J, Phan L, Smigielski EM, Sirotkin K. dbSNP: the NCBI database of genetic variation. Nucleic Acids Res 2001;29:308-11. doi: 10.1093/nar/29.1.308

80. Starska K, Bryś M, Forma E, Olszewski J, Pietkiewicz P, Lewy-Trenda I, Stasikowska-Kanicka O, Danilewicz M, Krześlak A. Metallothionein $2 A$ core promoter region genetic polymorphism and its impact on the risk, tumor behavior, and recurrences of sinonasal inverted papilloma (Schneiderian papilloma). Tumour Biol 2015;36:8559-71. doi: 10.1007/ s13277-015-3616-7

81. Starska K, Krześlak A, Forma E, Olszewski J, Lewy-Trenda I, Osuch-Wójcikiewicz E, Bryś M. Genetic polymorphism of metallothionein 2A and risk of laryngeal cancer in a Polish population. Med Oncol 2014;31:75. doi: 10.1007/s12032014-0075-8

82. Krześlak A, Forma E, Jóźwiak P, Szymczyk A, Smolarz B, Romanowicz-Makowska H, Różański W, Bryś M Metallothionein 2A genetic polymorphisms and risk of ductal breast cancer. Clin Exp Med 2014;14:107-13. doi: 10.1007/ s10238-012-0215-4

83. Kita K, Miura N, Yoshida M, Yamazaki K, Ohkubo T, Imai $\mathrm{Y}$, Naganuma A. Potential effect on cellular response to cadmium of a single-nucleotide $\mathrm{A} \rightarrow \mathrm{G}$ polymorphism in the promoter of the human gene for metallothionein IIA. Hum Genet 2006;120:553-60. doi: 10.1007/s00439-006-0238-6

84. Starska K, Bryś M, Forma E, Olszewski J, Pietkiewicz P, Lewy-Trenda I, Danilewicz M, Krześlak A. The effect of metallothionein $2 \mathrm{~A}$ core promoter region single-nucleotide polymorphism on accumulation of toxic metals in sinonasal inverted papilloma tissues. Toxicol Appl Pharmacol 2015;285:187-97. doi: 10.1016/j.taap.2015.04.008

85. Starska K, Krześlak A, Forma E, Olszewski J, MorawiecSztandera A, Aleksandrowicz P, Lewy-Trenda I, Bryś M. The $-5 \mathrm{~A} / \mathrm{G}$ singlenucleotide polymorphism in the core promoter region of $M T 2 A$ and its effect on allele-specific gene expression and $\mathrm{Cd}, \mathrm{Zn}$ and $\mathrm{Cu}$ levels in laryngeal cancer. Toxicol Appl Pharmacol 2014;280:256-63. doi: 10.1016/j. taap.2014.08.016

86. Krześlak A, Forma E, Chwatko G, Jóźwiak P, Szymczyk A, Wilkosz J, Różański W, Bryś M. Effect of metallothionein $2 A$ gene polymorphism on allele-specific gene expression and metal content in prostate cancer. Toxicol Appl Pharmacol 2013;268:278-85. doi: 10.1016/j.taap.2013.02.013

87. Forma E, Krzeslak A, Wilkosz J, Jozwiak P, Szymczyk A, Rozanski W, Brys M. Metallothionein 2A genetic polymorphisms and risk of prostate cancer in a Polish population. Cancer Genet 2012;205:432-35. doi: 10.1016/j. cancergen.2012.05.005

88. Białkowska K, Marciniak W, Muszynska M, Baszuk P, Gupta S, Jaworska-Bieniek K, Sukiennicki G, Durda K, Gromowski T, Prajzendanc K, Cybulski C, Huzarski T, Gronwald J, Debniak T, Scott RJ, Lubinski J, Jakubowska A. Association of zinc level and polymorphism in MMP-7 gene with prostate cancer in Polish population. PLoS One 2018;13:e0201065. doi: 10.1371/journal.pone.0201065

89. Tekin D, Kayaaltı Z, Aliyev V, Söylemezoğlu T. The effects of metallothionein $2 A$ polymorphism on placental cadmium accumulation: Is metallothionein a modifying factor in transfer of micronutrients to the fetus? J Appl Toxicol 2012;32:270-5. doi: 10.1002/jat.1661

90. Tekin D, Kayaaltı Z, Söylemezoğlu T. The effects of metallothionein $2 \mathrm{~A}$ polymorphism on lead metabolism: are pregnant women with a heterozygote genotype for metallothionein $2 A$ polymorphism and their newborns at risk of having higher blood lead levels? Int Arch Occup Environ Health 2012;85:631-7. doi: 10.1007/s00420-011-0711-y

91. Kayaaltı Z, Sahiner L, Durakoğlugil ME, Söylemezoğlu T. Distributions of interleukin-6 (IL-6) promoter and metallothionein $2 A(M T 2 A)$ core promoter region gene polymorphisms and their associations with aging in Turkish population. Arch Gerontol Geriatr 2011;53:354-8. doi: 10.1016/j.archger.2011.01.001

92. Kayaalti Z, Aliyev V, Söylemezoğlu T. The potential effect of metallothionein $2 A-5 \mathrm{~A} / \mathrm{G}$ single nucleotide polymorphism on blood cadmium, lead, zinc and copper levels. Toxicol Appl Pharmacol 2011;256:1-7. doi: 10.1016/j. taap.2011.06.023

93. Kayaalti Z, Söylemezoğlu T. The polymorphism of core promoter region on metallothionein $2 A$-metal binding protein in Turkish population. Mol Biol Rep 2010;37:185-90. doi: 10.1007/s11033-009-9586-3

94. Kayaalti Z, Mergen G, Söylemezoğlu T. Effect of metallothionein core promoter region polymorphism on cadmium, zinc and copper levels in autopsy kidney tissues from a Turkish population. Toxicol Appl Pharmacol 2010;245:252-5. doi: 10.1016/j.taap.2010.03.007

95. Hattori Y, Naito M, Satoh M, Nakatochi M, Naito H, Kato M, Takagi S, Matsunaga T, Seiki T, Sasakabe T, Suma S, Kawai S, Okada R, Hishida A, Hamajima N, Wakai K. Metallothionein MT2A A-5G polymorphism as a risk factor for chronic kidney disease and diabetes: cross-sectional and cohort studies. Toxicol Sci 2016;152:181-93. doi: 10.1093/ toxsci/kfw080

96. Hayashi Y, Hashizume T, Wakida K, Satoh M, Uchida Y, Watabe K, Matsuyama Z, Kimura A, Inuzuka T, Hozumi I. Association between metallothionein genes polymorphisms and sporadic amyotrophic lateral sclerosis in a Japanese population. Amyotroph Lateral Scler 2006;7:22-6. doi: 10.1080/14660820600618766

97. García M, Álvarez L, Fernández Á, González-Iglesias H, Escribano J, Fernández-Vega B, Villota E, Fernández-Vega Cueto L, Fernández-Vega Á, Coca-Prados M. Metallothionein polymorphisms in a Northern Spanish population with neovascular and dry forms of age-related macular degeneration. Ophthalmic Genet 2017;38:451-8. doi: 10.1080/13816810.2017.1288825

98. McElroy JA, Bryda EC, McKay SD, Schnabel RD, Taylor JF. Genetic variation at a metallothionein $2 A$ promoter singlenucleotide polymorphism in white and black females in Midwestern United States. J Toxicol Environ Health A 2010;73:1283-7. doi: 10.1080/15287394.2010.485067

99. Stajnko A, Slejkovec Z, Mazej D, France-Stiglic A, Briski AS, Prpic I, Spiric Z, Horvat M, Falnoga I. Arsenic metabolites; selenium; and $A S 3 M T, M T H F R, A Q P 4, A Q P$, SELENOP, INMT, and MT2A polymorphisms in CroatianSlovenian population from PHIME-CROME study. Environ Res 2019;170:301-19. doi: 10.1016/j.envres.2018.11.045

100. Liu D, Wang M, Tian T, Wang XJ, Kang HF, Jin TB, Zhang SQ, Guan HT, Yang PT, Liu K, Liu XH, Xu P, Zheng Y, Dai ZJ. Genetic polymorphisms (rs10636 and rs28366003) in 
metallothionein $2 A$ increase breast cancer risk in Chinese Han population. Aging (Albany NY) 2017;9:547-55. doi: 10.18632/aging. 101177

101. Shokrzadeh M, Mohammadpour A, Ghassemi-Barghi N, Hoseini V, Abediankenari S, Tabari YS. Metallothionein-2A (rs1610216\&rs28366003) gene polymorphisms and the risk of stomach adenocarcinoma. Arq Gastroenterol 2019;56:36771. doi: 10.1590/S0004-2803.201900000-69

102. González-Martínez F, Sánchez-Rodas D, Cáceres DD, Martínez MF, Quiñones LA, Johnson-Restrepo B. Arsenic exposure, profiles of urinary arsenic species, and polymorphism effects of glutathione-s-transferase and metallothioneins. Chemosphere 2018;212:927-36. doi: 10.1016/j.chemosphere.2018.08.139

103. Raudenska M, Dvorakova V, Pacal L, Chalasova K, Kratochvilova M, Gumulec J, Ruttkay-Nedecky B, Zitka O, Kankova K, Adam V, Masarik M. Levels of heavy metals and their binding protein metallothionein in type 2 diabetics with kidney disease. J Biochem Mol Toxicol 2017;31:e21891. doi: $10.1002 /$ jbt.21891

104. Adams SV, Barrick B, Christopher EP, Shafer MM, Makar KW, Song X, Lampe JW, Vilchis H, Ulery A, Newcomb PA. Genetic variation in metallothionein and metal-regulatory transcription factor 1 in relation to urinary cadmium, copper, and zinc. Toxicol Appl Pharmacol 2015;289:381-8. doi 10.1016/j.taap.2015.10.024

105. Yang CC, Chuang CS, Lin CI, Wang CL, Huang YC, Chuang HY. The association of the blood lead level and serum lipid concentrations may be modified by the genetic combination of the metallothionein $2 A$ polymorphisms rs $10636 \mathrm{GC}$ and rs28366003 AA. J Clin Lipidol 2017;11:234-41. doi: 10.1016/j.jacl.2016.12.010

106. Wang Y, Goodrich JM, Gillespie B, Werner R, Basu N, Franzblau A. An investigation of modifying effects of metallothionein single-nucleotide polymorphisms on the association between mercury exposure and biomarker levels. Environ Health Perspect 2012;120:530-4. doi: 10.1289/ ehp. 1104079

107. Pavić M, Turčić P, Ljubojević M. Forgotten partners and function regulators of inducible metallothioneins. Arh Hig Rada Toksikol 2019;70:256-64. doi: 10.2478/aiht-2019-703317

108. Baird SK, Kurz T, Brunk UT. Metallothionein protects against oxidative stress induced lysosomal destabilization. Biochem J 2006;394:275-83. doi: 10.1042/BJ20051143

109. Bresgen N, Eckl PM. Oxidative stress and the homeodynamics of iron metabolism. Biomolecules 2015;5:808-47. doi: 10.3390/biom5020808

110. El-Agha O, Gokmen GI. Smoking habits and cadmium intake in Turkey. Biol Trace Element Res 2002;88:31-43. doi: 10.1385/BTER:88:1:31

111. Esteban-Vasallo MD, Aragonés N, Pollan M, López-Abente G, Perez-Gomez B. Mercury, cadmium, and lead levels in human placenta: a systematic review. Environ Health Perspect 2012;120:1369-77. doi: 10.1289/ehp.1204952

112. Giacconi R, Cipriano C, Muti E, Costarelli L, Maurizio C, Saba V, Gasparini N, Malavolta M, Mocchegiani E. Novel $-209 \mathrm{~A} / \mathrm{G} M T 2 A$ polymorphism in old patients with type 2 diabetes and atherosclerosis: relationship with inflammation (IL-6) and zinc. Biogerontology 2005;6:407-13. doi: 10.1007/ s10522-005-4907-y
113. Giacconi R, Muti E, Malavolta M, Cipriano C, Costarelli L, Bernardini G, Gasparini N, Mariani E, Saba V, Boccoli G, Mocchegiani E. The $+838 \mathrm{C} / \mathrm{G} M T 2 A$ polymorphism, metals, and the inflammatory/immune response in carotid artery stenosis in elderly people. Mol Med 2007;13:388-95. doi: 10.2119/2007-00045

114. Kozarova R, Postadzhiyan A, Apostolova MD. Association of +1245 A/G MT1A and -209 A/G MT2A polymorphysms with coronary artery disease and diabetes mellitus in Bulgarian cohort. Biotechnol Biotec Eq 2012;26(Suppl 1):100-6. doi: 10.5504/50YRTIMB.2011.0019

115. Yang L, Li H, Yu T, Zhao H, Cherian M G, Cai L, Liu Y. Polymorphisms in metallothionein-1 and -2 genes associated with the risk of type 2 diabetes mellitus and its complications. Am J Physiol Endocrinol Metab 2008;294:E987-92. doi: 10.1152/ajpendo.90234.2008

116. Woods JS, Heyer NJ, Russo JE, Martin MD, Pillai PB, Farin FM. Modification of neurobehavioral effects of mercury by genetic polymorphisms of metallothionein in children. Neurotoxicol Teratol 2013;39:36-44. doi: 10.1016/j. ntt.2013.06.004

117. Yang XY, Sun JH, Ke HY, Chen YJ, Xu M, Luo GH. Metallothionein $2 A$ genetic polymorphism and its correlation to coronary heart disease. Eur Rev Med Pharmacol Sci 2014;18:3747-53. PMID: 25555862

118. Chen X, Lei L, Tian L, Zhu G, Jin T. Bone mineral density and polymorphisms in metallothionein $1 \mathrm{~A}$ and $2 \mathrm{~A}$ in a Chinese population exposed to cadmium. Sci Total Environ 2012;423:12-7. doi: 10.1016/j.scitotenv.2012.02.020

119. Fernandes KC, Martins AC Jr, Oliveira AÁ, Antunes LM, Cólus IM, Barbosa F Jr, Barcelos GR. Polymorphism of metallothionein $2 \mathrm{~A}$ modifies lead body burden in workers chronically exposed to the metal. Public Health Genomics 2016;19:47-52. doi: 10.1159/000441713

120. Gundacker C, Wittmann KJ, Kukuckova M, Komarnicki G, Hikkel I, Gencik M. Genetic background of lead and mercury metabolism in a group of medical students in Austria. Environ Res 2009;109:786-96. doi: 10.1016/j.envres.2009.05.003

121. Ganguly S, Taioli E, Baranski B, Cohen B, Toniolo P, Garte SJ. Human metallothionein gene expression determined by quantitative reverse transcription-polymerase chain reaction as a biomarker of cadmium exposure. Cancer Epidemiol Biomarkers Prev 1996;5:297-301. PMID: 8722222

122. Lu J, Jin T, Nordberg G, Nordberg M. Metallothionein gene expression in peripheral lymphocytes from cadmium-exposed workers. Cell Stress Chaperones 2001;6:97-104. doi: 10.1379/1466-1268(2001)006<0097

123. Chen L, Jin T, Huang B, Nordberg G, Nordberg M. Critical exposure level of cadmium for elevated urinary metallothionein - An occupational population study in China. Toxicol Appl Pharmacol 2006;215:93-9. doi: 10.1016/j. taap.2006.01.013

124. Huang ZY, Zhang Q, Chen J, Zhuang ZX, Wang XR. Bioaccumulation of metals and induction of metallothioneins in selected tissues of common carp (Cyprinus carpio L.) co-exposed to cadmium, mercury and lead. Appl Organomet Chem 2007;21:101-7. doi: 10.1002/aoc.1167

125. Figueira E, Branco D, Antunes SC, Gonçalves F, Freitas R. Are metallothioneins equally good biomarkers of metal and oxidative stress? Ecotoxicol Environ Saf 2012;84:185-90. doi: 10.1016/j.ecoenv.2012.07.012 
126. Mijošek T, Filipović MV, Dragun Z, Ivanković D, Krasnići N, Erk M, Gottstein S, Lajtner J, Sertić Perić, M, Matoničkin Kepčija, R. Comparison of electrochemically determined metallothionein concentrations in wild freshwater salmon fish and gammarids and their relation to total and cytosolic metal levels. Ecol Indicat 2019;105:188-98. doi: 10.1016/j. ecolind.2019.05.069

127. Theocharis SE, Margeli AP, Koutselinis A. Metallothionein: a multifunctional protein from toxicity to cancer. Int J Biol Markers 2003;8:162-9. doi: 10.1177/172460080301800302

128. Cherian MG, Jayasurya A, Bay B-H. Metallothioneins in human tumors and potential roles in carcinogenesis. Mutat Res 2003;533:201-9. doi: 10.1016/j.mrfmmm.2003.07.013

129. Bay BH, Jin R, Huang J, Tan PH. Metallothionein as a prognostic biomarker in breast cancer. Exp Biol Med (Maywood) 2006;231:1516-21. doi : $10.1177 / 153537020623100910$

130. Krizkova S, Masarik M, Majzlik P, Kukacka J, Kruseova J, Adam V, Prusa R, Eckschlager T, Stiborova M, Kizek R. Serum metallothionein in newly diagnosed patients with childhood solid tumours. Acta Biochim Pol 2010;57:561-6. doi: 10.18388/abp.2010 2444
131. Siddiqui S, Singh A, Alia S, Yadav M, Pandey V, Sharma D. Metallothionein: potential therapeutic target for osteosarcoma. J Oncol Sci 2019;5:13-8. doi: 10.1016/j.jons.2019.02.002

132. Mangelinck A, da Costa MEM, Stefanovska B, Bawa O, Polrot M, Gaspar N, Fromigué O. MT2A is an early predictive biomarker of response to chemotherapy and a potential therapeutic target in osteosarcoma. Sci Rep 2019;9:12301. doi: 10.1038/s41598-019-48846-2

133. Kwon JM, Goate AM. The candidate gene approach. Alcohol Res Health 2000;24:164-8. PMCID: PMC6709736

134. Witte JS, Visscher PM, Wray NR. The contribution of genetic variants to disease depends on the ruler. Nat Rev Genet 2014;15:765-76. doi: $10.1038 / \operatorname{nrg} 3786$

135. Goldstein DB. Common genetic variation and human traits. NEngl J Med 2009;360:1696-8. doi: 10.1056/NEJMp0806284

136. Hardy J, Singleton A. Genomewide association studies and human disease. N Engl J Med 2009;360:1759-68. doi: 10.1056/NEJMra0808700

137. Manolio TA. Genomewide association studies and assessment of the risk of disease. N Engl J Med 2010;363:166-76. doi: 10.1056/NEJMra0905980

\section{Polimorfizmi gena metalotioneina $2 A$ u ljudi i njihova povezanost s bolestima i razinama elemenata u tragu}

Metalotioneini u ljudskom organizmu povezana su skupina niskomolekularnih unutarstaničnih proteina, čiju sintezu mogu pobuditi esencijalni elementi, ponajprije $\mathrm{Zn} \mathrm{i} \mathrm{Cu}$, toksični elementi i druge kemijske tvari te razni uvjeti koji izazivaju stres u organizmu. Od četiriju poznatih izoformi metalotioneina u ljudskome tijelu, najčešći oblik je MT2. Izražaj metalotioneina kodira skupina povezanih gena i na to mogu utjecati polimorfizmi pojedinačnoga nukleotida u tim genima. Do sada su otkrivena 24 jednonukleotidna polimorfizma u području gena $M T 2 A$, s incidencijom od oko $1 \%$ u raznim skupinama stanovništva, a za tri je takva polimorfizma utvrđeno da bi mogli utjecati na fiziološke i patofiziološke procese. U preglednom radu prikazane su dosadašnje spoznaje o trima jednonukleotidnim polimorfizmima u genu $M T 2 A$ i njihove povezanosti s koncentracijama elemenata u zdravih i bolesnih osoba. Najviše istraživan jednonukleotidni polimorfizam gena $M T 2 A$ do sada bio je rs28366003 $(M T 2 A-5 \mathrm{~A} / \mathrm{G})$ i za njega su pokazane povezanosti s duljinom života, nekoliko tipova karcinoma (u dojki, prostati, grkljanu i sinusima) i s bubrežnim bolestima. Za drugi najviše istraživani polimorfizam rs10636 $(M T 2 A+838 \mathrm{G} / \mathrm{C})$ nađene su povezanosti s rakom dojke, bolestima srca i krvnih žila te dijabetesom tipa 2 . Za obje te vrste polimorfizama nađene su povezanosti i s koncentracijama metala i polumetala u organizmu. U samo nekoliko istraživanja ispitivana je povezanost polimorfizma rs1610216 (MT2A-209A/G) s dijabetesom tipa 2, kardiomiopatijom, hiperglikemijom i koncentracijama Zn. Podatci u literaturi upućuju na moguću praktičnu primjenu nalaza koncentracija metalotioneina i genskih polimorfizama $M T 2 A$ kao bioloških pokazatelja izloženosti metalima i kliničkih pokazatelja brojnih kroničnih bolesti. Za tu svrhu potrebna su daljnja opsežna istraživanja u velikom broju dobro definiranih skupina ispitanika (nekoliko stotina i tisuća), usredotočenih na određeno fiziološko ili patološko stanje te uzimajući u obzir druge čimbenike, kao što su okolišna izloženost, osobne životne navike te genetičke i epigenetičke značajke. 